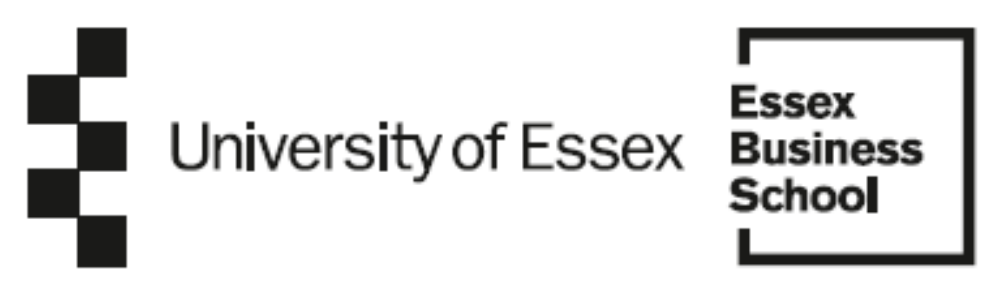

\author{
Essex Finance Centre \\ Working Paper Series
}

"How does standardization affect OTC markets? Evidence from the Small Bang reform in the CDS market"

"Radu-Dragomir Manac, Chiara Banti, Neil Kellard" 


\title{
How does standardization affect OTC markets? Evidence from the Small Bang reform in the CDS market
}

\author{
Radu-Dragomir Manac, Chiara Banti and Neil Kellard*
}

\begin{abstract}
Focusing on the most liquid segment of the European CDS market, this paper studies the impact of key standardization reforms. We document that the introduction of an upfront fee to standardize the cash flow of CDS contracts created an initial capital cost for traders, leading to higher CDS prices. This relation holds after accounting for well-known determinants of spreads, suggesting a separate funding channel driven by the greater capital intensity of trading. This effect is stronger when dealers are likely to bear the initial capital cost and is present across all industries, except for swaps written on financials.
\end{abstract}

\footnotetext{
* The three authors are affiliated to University of Essex, Wivenhoe Park, Colchester, Essex, CO4 3SQ, United Kingdom. Neil Kellard (corresponding author), nkellard@essex.ac.uk, tel. +44 (0) 1206 874153; Radu-Dragomir Manac,rmanac@essex.ac.uk; Chiara Banti, cbanti@essex.ac.uk.
} 


\section{Introduction}

Standardization is a key element in the on-going regulatory reforms of over-the-counter (OTC) markets. Contract standardization is a process that allows matching of cash flows in terms of amount and maturity. ${ }^{1}$ Indeed, contract standardization is essential for several aspects of Credit Default Swaps (CDS) trading, such central clearing and centralized trading. ${ }^{2}$ Moreover, standardized contracts facilitate netting and trade compression (Vause (2010)) and are necessary to attain a certain degree of liquidity on centralized trading venues (Oehmke and Zawadowski (2017)). However, standardized contracts may not be able to meet specific risk management and trading objectives, for which agents rely on the customized contracts of OTC markets (Stulz (2010)). While the literature has studied extensively the impact of central clearing on the functioning of derivative markets, ${ }^{3}$ the impact of reforms aimed at contract standardization has been relatively less studied. In this paper, we address this issue in the context of the regulatory reforms aimed at improving standardization of CDS contracts and study whether these reforms have affected the cost to insure against the default of an entity in CDS markets.

Following the excessive risk taking and poor practices that emerged during the Global Financial Crisis (GFC), a series of reforms aimed at promoting and facilitating standardization in the CDS markets have been introduced. One of the most notable reforms affecting the CDS market is the set of regulatory changes collectively known as the CDS Small Bang, introduced

\footnotetext{
${ }^{1}$ Standardization of CDS contracts can also involve default-contingent payments, restructuring clauses, and the events that trigger default (see Vause (2010) for more details).

2 The multilateral netting of positions via central counterparties requires standardized contracts, and a large share of contracts has to move to a central clearing counterparty for it to achieve the multilateral netting benefits sought by the regulators (IMF (2010)).

${ }^{3}$ Important contributions to the literature examining the impact of central clearing on the functioning of OTC markets include: Duffie and Zhu (2011), Duffie, Scheicher, and Vuillemey (2015), Acharya and Bisin (2014), Loon and Zhong (2014).
} 
in June 2009 in Europe. As standardisation increases the share of contracts cleared centrally (Vause (2010)), the reduction in counterparty risk should be reflected in lower costs of insurance against default in CDS. ${ }^{4}$ However, to standardize the heterogeneous cash flows of CDS contracts, the Small Bang has introduced fixed coupons together with an upfront fee payable at the start of the contract, whereas prior to the reform, CDS contracts did not carry any initial capital requirements. Thus, this regulatory change has made trading in CDS markets more capital intensive. As dealers sustain additional capital costs, the required risk premium to deal in CDS may increase under certain circumstances, increasing the cost to enter CDS contracts. Indeed, looking at the cost of investment-grade CDS contracts through time, we note that average CDS prices are higher in the post-reform period, and although CDS spreads have steadily declined following the peaks observed during the GFC and subsequent European Sovereign Debt Crisis, they have never reached the lows of their pre-GFC levels (Figure 1). A similar pattern holds true for CDS liquidity (Figure 2). Moreover, the greater capital requirements, coupled with declining dealer profitability caused by the unusually low market volatility (IMF (2015a), Callsen and Hill (2018)), may encourage greater concentration amongst dealers.

[Insert Figures 1 and 2 about here]

In this paper, we investigate the impact of the CDS Small Bang standardization reform on CDS markets, focusing on single-name investment grade companies included in the Markit iTraxx Europe index, the most liquid segment of the CDS market in Europe. The European market provides a unique setting to address this question. For example, compared to the US reforms, European regulation allows for greater flexibility in terms of contract specifications. ${ }^{5}$

\footnotetext{
${ }^{4}$ As insurance contracts against the default of an entity, CDS prices reflect the probability of default of the entity, as well as the default risk of the counterparty of the CDS contract, the so-called counterparty risk. Moreover, CDS prices comprise a risk premium capturing subjective factors such as dealer risk aversion (Siriwardane (2019)).

${ }^{5}$ A similar set of regulatory changes known as the CDS Big Bang was implemented in the US CDS market in April 2009. The US reforms defined only two fixed coupon rates of 100 bps and 500 bps, whereas the Small Bang introduced four fixed coupon rates of $25 \mathrm{bps}, 100 \mathrm{bps}, 500 \mathrm{bps}$, and $1000 \mathrm{bps}$.
} 
Moreover, European markets have experienced a crisis episode, the European debt crisis, after the protocol changes. Thus, focusing on European CDS markets we can assess the impact of the reforms across both relatively volatile and calm periods. Having documented higher CDS prices in the post-reform period compared to the period preceding the GFC, we concentrate on dealers and study why the changes introduced by the Small Bang affect CDS prices. In this respect, we study the introduction of the initial capital charge and its impact on CDS prices, focusing on different periods characterized by high and low volatility regimes. We further investigate this relationship by differentiating between instances in which the protection buyer bears the initial capital requirement, as opposed to their counterparty, in the context of dealers positioning themselves, on aggregate, as net protection buyers. Finally, following evidence in the literature about an inconsistent appraisal of credit risk for financial entities (Arora, Gandhi, and Longstaff (2012)), we study the effect of the initial capital charge on CDS price changes separately for financial and nonfinancial entities, and explore whether the relationship is industry contingent.

We find that, on average, the cost of insurance using CDS contracts has increased following the implementation of the Small Bang standardization reform. We relate this effect to the implications of the regulatory changes for dealers capital requirements and inventory management. Specifically, we document that higher initial capital charges positively impact CDS spread changes, resulting in higher CDS prices. The introduction of the initial capital charge is interpreted as an additional funding cost for the parties engaging in CDS transactions, creating a potential friction to trade in CDS. An initial capital charge increases dealers risk aversion leading to higher CDS prices. We document this effect while controlling for wellknown determinants of CDS spreads, including firm-specific volatility and liquidity factors, and macroeconomic variables capturing market conditions and sentiment (Ericsson, Jacobs, and Oviedo (2009), Tang and Yan (2010), Tang and Yan (2017), Corò, Dufour, and Varotto 
(2013)). To further confirm the funding channel, we show that the impact of the regulatory change is present especially when dealers, as net protection buyers, are more likely to bear the initial capital cost. Moreover, analysing different market conditions, we document that the impact of the fee on CDS prices is stronger in the most recent period following the European debt crisis when market conditions were relatively more benign. Finally, we document that the 'capital requirements - CDS price' relation is industry contingent. Financials are indeed the only industry sector, out of the five industries in which entities in the iTraxx Europe index are categorised, for which CDS prices do not increase due to the introduction of the initial capital cost. On the one hand, in line with the findings of Arora et al. (2012), this may suggest that counterparty risk is not priced for financials which points towards a greater benefit of standardisation in reducing counterparty risk. On the other hand, this may indicate that trading CDS written on financial entities is seen by dealers as essential to the good functioning of the market and, in conjunction with the high liquidity of financial firms CDS which are the most widely traded among industry sectors, the initial capital charge is seen as a relatively small barrier to trading.

We make three main contributions to the literature. First, we contribute to the nascent literature on the impact of post-GFC regulatory reforms focused on standardisation of OTC markets. Most studies focus on the impact of standardisation on liquidity. To this end, Wang, Wu, Yan, and Zhong (2021) and Daures-Lescourret and Fulop (2021) study CDS standardization reforms in the US and Europe, noting a positive impact on liquidity. However, unexpected consequences of the reforms have also emerged, including increased illiquidity for the CDS contracts with higher upfront capital charges (Wang et al. (2021)). In this paper, we provide evidence that CDS spreads widen due to the payment of the upfront fee following the adoption of the Small Bang reforms even after accounting for CDS liquidity and volatility, suggesting a separate, additional funding channel driven by the increase in capital intensity of 
engaging in CDS contracts. Secondly, we add to the literature examining the effects of funding constraints on financial markets (e.g. Brunnermeier and Pedersen (2009), He and Krishnamurthy (2013), Adrian, Etula, and Muir (2014), He, Kelly, and Manela (2017), Siriwardane (2019)). Studying CDS specifically, Siriwardane (2019) documents a sizeable impact of dealers capital shocks on CDS prices that is comparable in magnitude to that of standard credit factors. We contribute to this literature by identifying substantial regulatory spillovers on to dealers capital constraints. The requirement of payment of the initial upfront fee leads dealers to operate closer to their funding constraints, increases their risk aversion, and translates to higher CDS prices. Lastly, by documenting that the fee payable at the inception of a CDS contract following the Small Bang reforms acts as an additional funding cost which positively impacts CDS spread changes, increasing CDS prices, this paper contributes to the literature investigating the determinants of CDS spreads (e.g. Ericsson et al. (2009), Corò et al. (2013), Annaert, De Ceuster, Van Roy, and Vespro (2013), Galil, Shapir, Amiram, and BenZion (2014), Tang and Yan (2017), Anderson (2017)).

The rest of the paper is structured as follows. Section II details the institutional background, focusing on the regulatory reforms affecting the CDS market, dealer positions and market concentration. Section III describes the data, sample and variable construction, and summary statistics. Section IV presents the empirical methods employed and results. Section V outlines the robustness checks performed on our results. Section VI concludes.

\section{Institutional Background}

Regulatory reforms in the post-GFC period have limited dealers proprietary trading and increased capital requirements for dealing in OTC markets. As a result, dealers have become less willing to make markets and commit capital to warehouse risk, especially in fixed income, 
currency, and commodity markets (IMF (2015b)). This reduced market making activity is identified as one of the main causes of episodes of price dislocations in key markets (IMF (2015b)). In October 2014, the US Treasury yield dropped by 37 bps to quickly recover in what is known as flash rally. ${ }^{6}$ This extreme price move took place in one of the most liquid markets in the world. This episode is not isolated; other highly liquid markets have experienced extreme price moves, such as the Swiss franc crash in January 2015 and the Bund tantrum in April 2015 (IMF (2015b)). Just as regulatory changes in the wake of the GFC curbed dealers proprietary trading and increased capital requirements unexpectedly creating risk for financial stability, regulatory reforms to promote contract standardization may have unintended consequences.

\section{A. Regulatory Changes in the CDS Market}

Following concerns regarding the role of CDS during the GFC, the CDS market has been subject to a number of regulatory changes aimed at increasing the standardisation of contracts and improving the transparency, efficiency and stability of the market. ${ }^{7}$ However, as outlined below, despite their acknowledged benefits, CDS market regulatory changes have also oftentimes had unintended negative consequences.

One of the first major regulatory changes concerning the CDS market was the introduction of the CDS Big Bang and CDS Small Bang reforms on April $8^{\text {th }}, 2009$ and June $20^{\text {th }}, 2009$ impacting the American and European CDS markets, respectively. An important development brought about by these reforms is the standardisation of coupon payments, whereby fixed coupons together with an upfront fee payable at the start of the contract are introduced. In particular, the CDS Small Bang conventions restrict coupon rates to $25 \mathrm{bps}, 100$

\footnotetext{
${ }^{6}$ See IMF (2015a) for a discussion of the role of structural changes in the Treasury market, specifically on the change in dealers business model from market making and risk warehouse to brokerage and risk distribution.

${ }^{7}$ See Augustin, Subrahmanyam, Tang, and Wang (2014) for a detailed description of regulatory reforms in the CDS market.
} 
bps, 500 bps and 1000 bps. $^{8}$ Hence, following the Small Bang reforms, CDS contracts require the exchange of an upfront fee at the initiation of the contract to settle the present value of the difference between the CDS spread and the fixed coupon (Wang et al. (2021)). The difference is paid by the buyer (seller) if the fixed coupon is lower (higher) than the actual CDS spread. Prior to the 2009 Small Bang reform, there was no upfront payment at the initiation of the contract, coupons were based on the CDS spread, and the contract had zero net present value. ${ }^{9}$ Exploring the CDS Big Bang and Small Bang reforms, Wang et al. (2021) and DauresLescourret and Fulop (2021) find an improvement in aggregate CDS liquidity following the reforms, though the improvement is greatly reduced for contracts that incur larger upfront fees (Wang et al. (2021)). Moreover, Gündüz, Ongena, Tümer-Alkan, and Yu (2020) document that CDS buying costs decrease for non-dealer banks following the CDS Big Bang and Small Bang protocol changes, enabling such banks to extend more credit to affected firms and improve hedging. Separately, investigating the CDS Big Bang protocol changes, Narayanan and Uzmanoglu (2018) document a sharper decline in firm value for investment-grade firms compared to high-yield entities with traded CDS following the Big Bang. Finally, Danis (2017) uses the CDS Big Bang reforms as a natural experiment and focuses on the restructuring of distressed firms finding that participation rate among bondholders is lower if the company has CDS traded on its debt, while Gelpern and Gulati (2012) explore whether following the Big Bang, CDS contract interpretation has become more contextualist rather than textualist in nature. ${ }^{10}$

\footnotetext{
${ }^{8}$ In the US market, the CDS Big Bang reforms defined only two fixed coupon rates of $100 \mathrm{bps}$ and $500 \mathrm{bps}$.

${ }^{9}$ A second feature of these protocol changes relates to the standardisation of cash settlements in contractual CDS agreements following a credit event, the settlement price being decided through an auction mechanism (Augustin et al. (2014)).

${ }^{10}$ Credit Derivatives Determination Committees set up by ISDA following the CDS Big Bang to help market participants reach decisions on issues such as whether a credit event has occurred or whether an auction should be held state an interpretative approach to contract adjudication, with members performing their obligations 'in a commercially reasonable manner', while being 'sensitive to the broader context of the CDS market' (Gelpern and Gulati (2012), p. 364). However, contrasting this contextualist mission statement, the contract interpretation strategies adopted by ISDA for its credit derivatives contracts in the context of the Greek sovereign debt crisis
} 
In addition to the Big Bang and Small Bang reforms, the Dodd-Frank Act of July 2010, and the European Market Infrastructure Regulation (EMIR) of September 2010 have been introduced in US and European markets, respectively, to fulfil the commitment of G20 leaders from September 2009 of centrally clearing all standardised OTC derivatives contracts by the end of 2012. These policies focus on mandating central clearing, improving the monitoring of risks and concentrations of exposures, mitigating counterparty risk through the high capitalisation of clearing houses, improving market transparency and liquidity, increasing competition, and facilitating the multilateral netting of transactions at the end of each day (see Loon and Zhong (2016) and Augustin et al. (2014)). Indeed, several papers have highlighted the benefits of these reforms for reducing counterparty and systemic risk, as well as improving liquidity (e.g., Acharya and Bisin (2014); Loon and Zhong (2016)). However, other studies have also pointed towards potential downsides of these reforms, such as a trade-off between increased multilateral netting and decreased bilateral netting of contracts (Duffie and Zhu (2011)), increased collateral demands following central clearing through a central counterparty (Sidanius and Zikes (2012)), and potential increased systemic risk and costs of risk management (McBride (2010)).

\section{B. CDS Market Evolution, Dealer Positions and Concentration}

Same as other OTC markets, the CDS market is a two-tier market, with a dealercustomer tier where smaller banks and other financial institutions deal with a market maker, and an interdealer segment where dealers trade among each other to adjust their inventory (Peltonen, Scheicher, and Vuillemey (2014)). Following the regulatory reforms impacting the CDS market in the aftermath of the GFC, notional amounts outstanding of CDS have decreased

'emphasised fidelity to contract text as distinct from economic substance of the transaction'(Gelpern and Gulati (2012), p. 385). 
sharply from over $\$ 44.9$ th at the end of 2008 to just over $\$ 7.5$ th at the end of 2019 according to BIS data. ${ }^{11}$

The CDS market is also increasingly concentrated, with the drivers of this trend to be found in regulation and market conditions. On one hand, bank capital requirements, and the leverage ratio in particular, have increased the capital cost of market making (IMF (2014), Callsen and Hill (2018)). On the other hand, low CDS volatility has reduced market makers' profitability. These conditions have led to an overall decline in the liquidity provision of market makers, with some dealers exiting the market (Callsen and Hill (2018)). ${ }^{12}$ Atkeson, Eisfeldt, and Weill (2013) argue that the high concentration observed in the CDS market is largely due to the fixed entry costs faced by new entrants, enabling only few large banks with large risk exposures (that can be hedged) to enter the market as dealers and provide intermediation, while medium-sized banks participate comparatively less in the OTC market and act as customers. Moreover, these large banks can support large notional CDS exposures by netting positions and holding collateral only proportional to their net exposures (Bolton and Oehmke (2013), Atkeson et al. (2013)). Relying on position data for global sovereign and financial single-name CDS, Peltonen et al. (2014) find that as of year-end 2011 only $18 \%$ of traders are net protection sellers, while $82 \%$ of traders are net buyers. Moreover, Siriwardane (2019) noted that by 2016 the top five buyers and top five sellers account for around half of aggregate net buying and net selling, respectively. DTCC data shows that between 2008 and 2019, on aggregate, four of the largest CDS dealers (Morgan Stanley, Goldman Sachs, J.P. Morgan and Citigroup) are net protection buyers, as shown in the CDS positions data presented in Table $1 .^{13}$

\footnotetext{
${ }^{11}$ The interdealer trading activity has also been declining steadily, mainly due to the increasing share of centrally cleared dealer transactions (Aldasoro and Ehlers (2018)).

${ }^{12}$ A report by the FSB (2017) report refers to market intelligence suggesting a decline in the number of dealers in OTC markets. Drawing on market surveys, IMF (2010) shows that balance sheet capacity and regulatory changes are major factors constraining market making activity in bond markets.

${ }^{13}$ Data on the amounts of CDS protection written and purchased of four large CDS dealers (Morgan Stanley, Goldman Sachs, JP Morgan and Citigroup) has been collected from the TIW reports from the DTCC between 2008 and 2019. Amounts of CDS protection bought and sold are not reported before 2008 .
} 
[Insert Table 1 about here]

We note that aggregate amounts of CDS protection bought and sold by the four largest dealers have steadily decreased through time, with the aggregate amounts of CDS bought and sold in 2019 being more than six times smaller than those seen in 2008 , in line with the general decrease in notional amounts of CDS outstanding observed after the GFC. Throughout our sample, the aggregate CDS position of the four largest dealers account for between $33.7 \%$ and $45.4 \%$ of the total gross notional amount of CDS bought and sold, indicating a high degree of concentration in the market. Figure 3 displays the share of aggregate notional amounts of bought and sold CDS by the four major dealers as a proportion of the total notional amount of CDS bought and sold over time, confirming that concentration in the CDS market has steadily increased following the GFC.

[Insert Figure 3 about here]

\section{Data and Variables}

\section{A. Data Collection and Sample Construction}

We source CDS spread mid, bid, and ask quotes for CDS contracts written on European investment-grade companies included in the Markit iTraxx Europe index from Bloomberg. The Markit iTraxx Europe index comprises of 125 investment-grade entities with the most liquid single-name CDS in the European market. ${ }^{14}$ The constituent list includes 100 non-financial firms and 25 companies that operate in the financial sector.

\footnotetext{
14 Previous studies using data from the iTraxx Europe index include Alexander and Kaeck (2008) and Breitenfellner and Wagner (2012) which examine the determinants of the CDS indices, Berndt and Obreja (2010) who use index data to construct a factor mimicking economic catastrophe risk, Junge and Trolle (2015) who construct a new measure of CDS market liquidity and analyse whether liquidity risk impacts expected CDS returns, and Hui, Lo, and Lau (2013) who explore option implied correlation between iTraxx Europe Financials and Non-Financials indexes.
} 
Our dataset includes monthly, end of month, observations spanning a period of fourteen years, from January 2006 to December $2019 .{ }^{15}$ Therefore, the sample covers a period of around three and a half years (41 months) prior and ten and a half years (127 months) after the CDS Small Bang. The entities in the dataset are all the companies included in Markit iTraxx Europe index throughout our sample period and for which we could source CDS and stock data from Bloomberg. To preserve the number of entities in our cross-section as well as maintain the most liquid CDS in our sample, we keep only reference entities that have not been excluded from the Markit iTraxx Europe index for more than ten index rolls throughout our sample period. ${ }^{16}$ We focus on CDS contracts with a five-year maturity as these contracts are the most liquid and widely traded (Annaert et al. (2013)). All contracts are denominated in Euros and have a Modified-Modified restructuring clause, the most common restructuring rule in Europe. The final sample consists of 17,375 (104 firms) monthly observations.

\section{B. Variable Description and Summary Statistics \\ 1. The Upfront Fee}

Computing the upfront fee requires two components, the distance between the CDS spread and the coupon rate, and the prevailing funding cost in the market. Since in our sample we cannot directly observe the upfront fee size and coupon rate, we follow Wang et al. (2021) and use the coupon rate closest to the CDS spread to obtain the distance between the spread and the coupon. ${ }^{17}$ Thus, for each reference entity $i$ in month $t$, we construct a variable $\left(D I S_{i, t}\right)$

\footnotetext{
${ }^{15}$ The sample start date is chosen due to relatively low CDS data availability prior to 2006.

${ }^{16}$ The European Markit iTraxx index constituent list is reviewed with respect to liquidity and investment grade of entities every six months, with one index roll occurring in March and one in September. Throughout the time frame of the study, the constituent list of the European iTraxx index changes are minor. This observation is also highlighted by Breitenfellner and Wagner (2012) who find only negligible effects of index roll changes on spread changes.

${ }^{17}$ In our sample, the coupon closest to the spread is in 5357 cases $(40.56 \%)$ at $25 \mathrm{bps}$, in 7639 cases $(57.84 \%)$ at $100 \mathrm{bps}$, in 207 cases (1.57\%) at $500 \mathrm{bps}$ and in 5 cases $(0.03 \%)$ at $1000 \mathrm{bps}$, highlighting the investment grade nature and liquidity of CDS of the reference entities.
} 
measuring the minimum difference, in absolute terms, between the CDS spread of firm $i$ in month $t$ and the four possible coupon rates, as shown in equation (1).

$$
D I S_{i, t}=\min \left(\left|C D S_{i, t}-25\right|,\left|C D S_{i, t}-100\right|,\left|C D S_{i, t}-500\right|,\left|C D S_{i, t}-1000\right|\right)
$$

To measure the funding cost per unit of payment prevailing in the market, we use the European TED spread, measured as the difference between the 3-month Euribor rate and 3month German Government BuBill rate. We choose to use the European TED spread as the funding cost measure for our main analysis as Cerutti, Claessens and Ratnovski (2017) convincingly show that European bank conditions, proxied through the European TED spread are better indicators of cross-border bank flows, especially outside of the GFC, compared to US banking conditions. However, in Section V.C we show that our results are robust to using the US TED spread as the funding cost measure. We obtain end-of-month closing values of the European TED spread from Bloomberg, noting a great deal of variation, ranging from lows of just over 2 bps to highs of 282 bps during the most turbulent part of the GFC.

Following Wang et al. (2021), we define the upfront fee $\left(F e e_{i, t}\right)$ as the product between the distance to the closest coupon $\left(D I S_{i, t}\right)$ and the funding cost prevailing in the market $\left(T E D\right.$ spread $\left._{t}\right)$, as shown in equation (2).

$$
\mathrm{Fee}_{i, t}=\text { DIS }_{i, t} \times T E D \text { spread }_{t}
$$

We note that the mean fee at the 25 bps coupon is $7.02 \mathrm{bps}$, at the 100 bps coupon this is $16.75 \mathrm{bps}$, at the $500 \mathrm{bps}$ coupon this is $66.82 \mathrm{bps}$, while at the $1000 \mathrm{bps}$ coupon the mean fee is 60.38 bps. As expected, we see that the fee increases, in absolute terms, with the coupon rate. ${ }^{18}$ In our sample, the average fee relative to the CDS spread equals $15.8 \%$ which indicates that the fee is also economically significant. The fee is paid by the protection buyer (seller)

\footnotetext{
18 The lower mean fee for the 1000 bps coupon can be attributed to a very low number of observations at this coupon rate (5 observations).
} 
when the spread is higher (lower) than the closest fixed coupon. In our sample, the protection buyer bears the upfront fee in $62.4 \%$ of cases.

Figure 4 presents the variation of the average fee observed in our post-Small Bang sample over time. We note that the mean fee hovered around $20 \mathrm{bps}$ in the period following the Small Bang and prior to the inception of the European Debt Crisis, then spiked sharply during the European Debt Crisis period, reaching levels of 95 bps in November 2011. ${ }^{19}$ The large spike in the fee during the European Debt Crisis can be attributed to the increases in funding costs during this period. The mean fee then fell considerably to averages of around 10 bps in the period following the European Debt Crisis.

[Insert Figure 4 about here]

\section{Control Variables}

The control variables included are drawn from the literature and consist of welldocumented firm-specific and macroeconomic determinants of CDS spreads and spread changes (see Ericsson et al. (2009), Tang and Yan (2010), Tang and Yan (2017), Corò et al. (2013)). As control variables, we therefore include firm-specific variables such as CDS illiquidity (CDS bid-ask spreads), 30-day realized CDS spread volatility, stock return, stock bid-ask spread (scaled by the midpoint of the bid and ask quotes), 30-day realized stock volatility, as well as macroeconomic variables such as the 10 -year risk-free rate prevailing in Europe, the slope of the yield curve (the difference between the 10-year and 2-year Euro-area Government bond yields), and the level of the VSTOXX index to measure implied volatility. ${ }^{20}$

\footnotetext{
${ }^{19}$ We follow Acharya, Eisert, Eufinger, and Hirsch (2018) and Acharya, Eisert, Eufinger, and Hirsch (2019) and consider the most severe part of the European Debt Crisis to last from January 2010 until July 2012 when the Outright Monetary Transactions (OMT) program was launched which indirectly recapitalized European banks and reestablished market stability.

${ }^{20}$ Following Pires, Pereira and Martins (2015), we focus on the absolute rather than the relative bid-ask spread as the authors convincingly show that the absolute measure should be used in the context of the CDS market. Contrasting this, stock bid-ask spreads are scaled by the midpoint of the bid and ask quotes, as commonly used in microstructure empirical research.
} 
To assemble our control variables, we obtain CDS bid and ask quotes as well as stock level data and macroeconomic series from Bloomberg.

\section{Summary Statistics}

Table 2 reports the summary statistics of the dataset. Panel A shows that the mean and median CDS spread throughout our sample is 85.99 bps and 66.46 bps, respectively. Panel B and Panel C display summary statistics for the pre-Small Bang and post-Small Bang samples, respectively.

\section{[Insert Table 2 about here]}

Comparing the CDS spread levels in the two regimes, we note that mean (median) spreads are larger in the post-Small Bang period, increasing from $75.40 \mathrm{bps}$ ( $45.69 \mathrm{bps}$ ) to 89.33 bps (70.56 bps). We also note that CDS liquidity has deteriorated on average after the Small Bang, CDS mean (median) bid-ask spreads reaching levels of 6.09 bps (5.30 bps) in the postSmall Bang period, compared to $5.97 \mathrm{bps}(4.10 \mathrm{bps})$ in the pre-Small Bang sample.

C. CDS Spreads and Liquidity Around the Small Bang: A Short and a Long-Term View

Figure 1 Graph B shows the evolution of CDS spreads using a 6-month window before and after the Small Bang event. We note that spreads have steadily decreased from levels of around 200 bps observed in March 2009 and have continued their decreasing trend after the Small Bang event of June 2009, reaching levels of around 76 bps at the end of the 2009 . However, looking at the long-term picture of average spread behavior throughout our whole sample, displayed in Figure 1 Graph A, we see that cross-sectional average spreads not only increased relatively soon after the Small Bang, possibly also due to the European Debt Crisis, 
but they do not approach their average pre-GFC level until the end of our sample. ${ }^{21}$ This is further evidenced by the smaller value of average CDS spread levels observed in the period preceding the Small Bang reforms (74.3bps), compared to that following the Small Bang (89.3bps), considering that the former period also includes the most turbulent part of the GFC. We argue that spreads have not declined to their pre-GFC levels, also in part, due to the increase in capital intensity brought about by the introduction of upfront fees for transacting CDS.

A similar behaviour to that of spreads is also seen in terms of CDS illiquidity. Consistent with the objectives of the Small Bang regulatory changes of improving transparency, standardization, and market liquidity, average CDS bid-ask spreads have steadily declined after the GFC and consequently, liquidity has improved in the short-run after the Small Bang reforms were enacted (see Figure 2 Graph B). However, taking a long-term perspective, we note that cross-sectional average CDS liquidity has not reached the average pre-GFC level following the Small Bang (see Figure 2 Graph A).

\section{Results}

This section details the empirical results of our estimations examining the effects of the upfront fees introduced following CDS Small Bang convention changes on CDS spreads. In the empirical analysis, we focus on examining spread changes, rather than spread levels for two reasons. Firstly, by using spread changes, we alleviate any non-stationarity concerns around CDS spreads, and independent variables. ${ }^{22}$ Moreover, as Ericsson et al. (2009) note, spread differences should be harder to explain than spread levels. Therefore, by performing our

\footnotetext{
${ }^{21}$ Following Corò et al. (2013) we consider the start month of the GFC to be April 2007.

${ }^{22}$ Previous studies investigating the determinants of CDS spread changes in the European market (Corò et al. (2013)) and in the U.S. market (Galil et al. (2014)) found evidence of non-stationarity in spread levels, whereas spread changes are stationary.
} 
estimations in first differences, we perform a stricter test of the effects of the upfront fees, as well as of other CDS determinants, on CDS spreads. ${ }^{23}$

\section{A. The Effect of the Small Bang Upfront Fee on CDS Spreads}

After documenting that CDS spreads are higher on average following the Small Bang reform, we next turn to a more formal analysis to identify the potential sources of this increase by focusing on the newly introduced initial charge. To assess whether the upfront fees brought about by the CDS Small Bang reforms increase CDS spreads after accounting for known firmlevel and macroeconomic determinants of CDS spreads, we estimate the model presented in equation (3):

$$
\Delta C D S_{i, t}=c_{i}+\beta_{1} \Delta F e e_{i, t}+\beta_{2}\left(\Delta F e e_{i, t} \times S B_{t}\right)+\gamma_{1} \Delta X_{i, t}+\gamma_{2} \Delta Y_{t}+u_{i}+\varepsilon_{i, t}
$$

In equation (3) $\triangle C D S_{i, t}$ is the change in the CDS spread for trading CDS contract $i$ on month $t, c_{i}$ is a constant, $\Delta F e e_{i, t}$ represents the change in the upfront fee on contract $i$ on month $t, S B_{t}$ is an indicator variable that equals one after the Small Bang event of June 2009, and zero otherwise, $\Delta X_{i, t}$ is the first difference of the set of firm-level control variables described in section III.B.2, $\Delta Y_{t}$ is the first difference of the set of macroeconomic variables described in section III.B.2, and $u_{i}$ are the firm-level fixed effects.

\section{[Insert Table 3 about here]}

Results are presented in Table 3. The model presented in equation (3) is first estimated on the whole time-series sample, without the inclusion of the terms $\beta_{1} \Delta F e e_{i, t}$ and $\beta_{2}\left(\Delta F e e_{i, t} \times S B_{t}\right)$ in column (1) to examine the determinants of CDS spreads without the inclusion of the upfront fee effects. Consistent with prior findings in the literature, we find that CDS spreads increase with stock and CDS volatility, stock and CDS illiquidity, and market

\footnotetext{
23 Previous studies exploring the determinants and commonality of CDS spread changes include Ericsson et al. (2009), Corò et al. (2013), Annaert et al. (2013), Galil et al. (2014), Tang and Yan (2017), and Anderson (2017).
} 
implied volatility, and decline with stock returns and the risk-free rate. In column (2), we estimate the full version of equation (3) and find that the coefficient of the interaction term $\Delta F e e_{i, t} \times S B_{t}$ is 0.14 and statistically significant at the $10 \%$ level $(t=1.96)$ highlighting the effect of the upfront fee on spread changes.

Next, we present results of the estimation of equation (3) in the sub-samples identifying the post Small Bang period (column (3)), the period between the Small Bang and the end of the European Debt Crisis (column (4)) and the post-European Debt Crisis period (column (5)). We find that after the Small Bang, CDS spreads increase significantly with the fee (column 3). In particular, a $1 \%$ increase in the fee is associated with a $0.28 \%$ increase in CDS spreads. The effect is significant across the two subperiods post Small Bang (columns 4 and 5), but it is especially large in the period following the European Debt Crisis (August 2012 - December 2019), highlighting the increased impact that the Small Bang fee has on widening CDS spreads in recent times. This finding also suggests that the effect of the fee is not directly related to the turbulent market episodes related to the crisis. In this latest period, a $1 \%$ increase in the fee is associated with a $0.74 \%$ increase in CDS spreads. ${ }^{24}$

Importantly, the widening of CDS spreads due to the payment of upfront fees is observed after controlling for known determinants of CDS spreads, including CDS illiquidity and volatility. Therefore, we propose that the exchange of upfront fees between CDS buyers and sellers increases CDS spreads through a funding channel that is separate from the liquidity or volatility transmission channels. ${ }^{25}$

\footnotetext{
${ }^{24}$ We note that results of the model presented in equation (3) are robust to an alternative specification whereby all independent variables, and not just the fee variable, are interacted with the dummy variable capturing the period following the Small Bang reforms. Results are presented in the Appendix in Table A1. As the interaction terms between the other independent variables and the Small Bang dummy are largely insignificant, and the results with respect to the upfront fee are qualitatively similar, we choose to report the results of the model presented in equation (3) for parsimony.

${ }^{25}$ In their study of the effects of the introduction of upfront fees following the CDS Big Bang and CDS Small Bang reforms on CDS liquidity, Wang et al. (2021) find that CDS bid-ask spreads increase due to the exchange of upfront fees.
} 


\section{B. Asymmetric Effects of the Upfront Fee on CDS Spreads \\ 1. The Effect of the Buyer Paying the Upfront Fee}

In this section we establish whether an asymmetric effect of the upfront costs on CDS spreads occurs, dependent on whether the upfront fee payer is the CDS buyer or seller. As shown in Section II.B, the four large CDS dealers are, on aggregate, net protection buyers in every year following the CDS Small Bang. Therefore, we posit that the effect of the upfront fee on CDS spreads is larger when the CDS contract buyer pays the upfront fee as this would constitute an additional funding cost that, on aggregate, CDS dealers would have to bear to engage in CDS transactions. To test this, we first construct an indicator variable Buyer $_{i, t}$ which takes the value of 1 if the CDS spread on contract $i$ in month $t$ is larger than the closest fixed coupon, and 0 otherwise. We then estimate the regression model presented in equation (4).

$$
\begin{aligned}
\Delta C D S_{i, t} & =c_{i}+\beta_{1} \Delta F e e_{i, t}+\beta_{2}\left(\Delta F e e_{i, t} \times \text { Buyer }_{i, t}\right)+\beta_{3}\left(\Delta \text { Fee }_{i, t} \times \text { Buyer }_{i, t} \times S B_{t}\right) \\
& +\gamma_{1} \Delta X_{i, t}+\gamma_{2} \Delta Y_{t}+u_{i}+\varepsilon_{i, t}
\end{aligned}
$$

[Insert Table 4 about here]

The estimation results are reported in Table 4. Examining the coefficient of the triple interaction term $\Delta F e e_{i, t} \times$ Buyer $_{i, t} \times S B_{t}$, presented in column (1), we find a point estimate of 0.28 that is statistically significant at the $1 \%$ significance level $(t=2.72)$. This provides evidence of the asymmetric effect of the protection buyer paying the upfront fee following the Small Bang reforms.

Focusing on the post-Small Bang period, in column (2) the point estimate of the coefficient on the term $\Delta F e e_{i, t} \times$ Buyer $_{i, t}$ is $1.17(t=3.83)$ which is more than four times larger than the point estimate of the fee coefficient observed in the baseline model reported in 
column (3) of Table 3. This suggests that the impact of the fee is especially large when the buyer pays. In columns (3) and (4) we isolate the period between the Small Bang and the European Debt Crisis, and the post-European Debt Crisis period, respectively, and we find that the coefficients of the interaction term $\Delta F e e_{i, t} \times$ Buyer $_{i, t}$ are $0.94(\mathrm{t}=3.31)$ and $2.74(\mathrm{t}=$ 8.89), respectively, indicating that the asymmetric effect of the buyer paying the upfront fee on CDS spreads is considerably larger in the post-European Debt Crisis period (August 2012 December 2019).

In conclusion, we document that the impact of the fee on CDS spreads is especially strong when dealers are more likely to bear this additional funding cost at the onset of the contract. We also show that this effect is economically meaningful and strong in the most recent period.

\section{Examining Financial and Non-Financial Companies Separately}

In this section, we investigate whether the impact of the fee on CDS spread depends on the industry of the underlying entity. It is important to note that significant differences between financial and non-financial firms exist, among others, in terms of regulation, funding methods, corporate governance, agency problems, capital structure, leverage levels, and calculation of distance to default (De Haan and Vlahu (2016) and Duan and Wang (2012)). Furthermore, inter alia, Alexander and Kaeck (2008) provide evidence that several variables that affect CDS spreads of non-financial entities do not influence spreads of companies operating in the financial sector.

Therefore, to check whether the effects of the upfront fees on CDS spreads differ when examining contracts written on financial or non-financial entities, we split our sample of firms 
according to whether they operate in a non-financial or financial industry, and estimate equation (5) separately on the two groups of firms. ${ }^{26}$

$$
\Delta C D S_{i, t}=c_{i}+\beta_{1} \Delta F e e_{i, t}+\gamma_{1} \Delta X_{i, t}+\gamma_{2} \Delta Y_{t}+u_{i}+\varepsilon_{i, t}
$$

[Insert Table 5 about here]

Table 5 presents the results. Columns (1) and (2) explore the effects of the upfront fees on CDS spread of financial entities for the whole time-series sample and post-Small Bang sample, respectively, while columns (3) and (4) explore the effects of the upfront fees on CDS spreads of non-financial entities for the whole time-series sample and post-Small Bang sample, respectively. We note that increases in upfront fees widen CDS spreads when examining the whole time-series sample for both financials and non-financials alike, with the point estimate of the coefficient of the term $\Delta F e e_{i, t}$ being slightly larger for financial entities compared to non-financials $(0.17(t=3.39)$ compared $0.14(t=5.15))$. Interestingly however, when focusing on the post-Small Bang sample, we find that changes in upfront fees do not significantly increase CDS spreads for financial entities, while the effect on non-financial entities almost doubles in magnitude, the point estimate of the coefficient of the term $\Delta F e e_{i, t}$ becoming 0.37 $(t=5.51)$

3. Is the Effect of the Upfront Fee on Spread Changes Industry Contingent?

The result from Section IV.B.2 seems surprising and calls for a deeper investigation into whether the impact of the Small Bang upfront fees on CDS spreads is contingent on the industry sector in which the underlying entity resides, firstly to explore whether there are other industries where the relationship does not hold, and secondly to check that the results found for the sub-sample including financial entities only are not primarily driven by the smaller sample size. To examine whether the effects of the upfront fee on CDS spreads are captured differently

\footnotetext{
${ }^{26}$ In our sample, we have 20 firms operating in the financial sector and 84 firms operating in non-financial sectors.
} 
across different industry sectors, we use the following procedure. First, we group firms in the iTraxx Europe index into one of five industry sectors as indicated by Markit. The five categories are: Automobile \& Industrials, Consumer Products, Energy, Financials, and Telecommunications, Media \& Technology. We then estimate the model presented in equation (6) separately for all time-series samples.

$$
\Delta C D S_{i, t}=c_{i}+\sum_{k=1}^{5} \beta_{k}\left(\Delta F e e_{i, t} \times I_{\text {sector }_{k}}\right)+\gamma_{1} \Delta X_{i, t}+\gamma_{2} \Delta Y_{t}+u_{i}+\varepsilon_{i, t}
$$

In equation (6), $I_{\text {sector }_{k}}$ represent dummy (indicator) variables taking the value of one if company $i$ is in sector $k$, and zero otherwise.

\section{[Insert Table 6 about here]}

Regression estimation results are reported in Table 6. Column (1) presents results for the whole time-series sample, while columns (2), (3) and (4), present results for the post-Small Bang sample, the sample covering the post-Small Bang period until the end of the European Debt Crisis, and the post-European Debt Crisis period, respectively. Examining the whole sample results, we find that the upfront fee significantly increases CDS spreads for all industries except consumer products. However, looking at the post-Small Bang period, we find that upfront fees increase spreads for all individual industry sectors except financials, providing further support to our previous results indicating that upfront fees increase CDS spreads of companies in the post-Small Bang period, with the exception of financial entities. Moreover, this alleviates any concerns that the results presented in Table 5 are due to lower number of financial entities, compared to non-financials. Upon further inspection of columns (3) and (4), we find that the result concerning financial companies is mostly due to the period between the Small Bang date and the end of the European Debt Crisis, as the relationship between the upfront fee and CDS spreads is significant and larger in magnitude in the post-European debt crisis period for all industry sectors, including financials. 
Although puzzling, since, in theory, the relationship between the Small Bang upfront fees and CDS spreads should not be dependent on the industry sector in which the underlying entity activates, as the fees would have to be exchanged between the counterparties in the transaction irrespective of the underlying entity, this result echoes previous findings of Arora et al. (2012) who show that CDS dealers' counterparty risk is priced when trading CDS written on entities from all industry sectors, except for financials. An implication of this result may be that the standardization benefits of the Small Bang reforms clearly outweigh the downside of the need for increased capital to engage in CDS transactions in the case of trading CDSs written on financial entities, due to a negligible impact of counterparty risk on spreads. Moreover, this result may suggest a market expectation that CDS dealers would not fail, even if large financial firms become distressed (Arora et al. (2012)). Potentially, this could further indicate a too-bigto-fail argument, whereby spreads of large financial entities would not increase due to the upfront fee as these financial companies could be considered essential to the functioning of financial markets and would thus be likely to receive assistance and/or bailouts in case they become vulnerable.

\section{Robustness checks}

\section{A. Do Spreads Increase Due to the Upfront Fees at the Market Level?}

Having documented that CDS spreads widen as a result of the introduction of upfront fees at the company level, we now turn our attention to replicating our main findings at the market level, by using cross-sectional averages of our dependent and independent variables, respectively. Hence, we estimate the regression presented in equation (7).

$$
\Delta \text { Market CDS }{ }_{t}=c_{t}+\beta_{1} \Delta \text { Market Fee } e_{t}+\beta_{2}\left(\Delta \text { Market Fee } e_{t} \times S B_{t}\right)+\gamma_{1} \Delta X_{t}+\varepsilon_{t}
$$


In equation (7), $\Delta$ Market $C D S_{t}$ is the first difference of the average market-wide CDS spread in month $t, c_{t}$ is a constant, $\Delta$ Market Fee ${ }_{t}$ is the first difference of the average market-wide upfront fee in month $t, S B_{t}$ is an indicator variable that equals one after the Small Bang event of June 2009, and zero otherwise, and $\Delta X_{t}$ represents first differences of the set of market-wide control variables described in section III.B.2.

\section{[Insert Table 7 about here]}

Results are presented in Table 7. We find compelling evidence supporting our previous firm level results. Upfront fees significantly increase CDS spreads at the market level. We find that the coefficient of $\Delta$ Market Fee $_{t}$ is positive and statistically significant in all estimations. The coefficient of the interaction term $\Delta$ Market Fee ${ }_{t} \times S B_{t}$ is 0.34 and is also statistically significant. Moreover, analyzing post-Small Bang subsamples, we show that the effect is almost three times stronger following the European Debt Crisis.

\section{B. Using Only CDS Big Bang Fixed Coupons in the Calculation of the Upfront Fee}

An interesting difference between the CDS Small Bang and CDS Big Bang reforms is that, in Europe, the Small Bang introduced four fixed coupons (25bps, 100bps, 500bps and $1000 \mathrm{bps}$ ), while in the US only two fixed coupons (100bps and 500bps) have been adopted. However, reports suggest that the European CDS market has shifted towards using the 100bps and 500bps coupons almost exclusively, with corporate investment grade swaps likely trading at 100bps, while high yield credits trade with a 500bps strike (see ECB (2009)). This shift is another indicator of a general move towards greater standardization as it brings CDS contracts traded in the European market in line with the standardized North American contracts.

To check whether our results are robust to the use of only (or primarily) the 100bps and 500bps coupons when transacting CDS contracts, we compute $D I S_{B B_{i, t}}$ as the minimum value 
of the absolute difference between one of the two fixed coupons and the CDS spread of firm $i$ in month $t$, as shown in equation (8):

$$
D I S_{B B_{i, t}}=\min \left(\left|C D S_{i, t}-100\right|,\left|C D S_{i, t}-500\right|\right)
$$

As in the main analysis, the fee $\left(F e e_{B B_{i, t}}\right)$ is computed as the product between the $D I S_{B B_{i, t}}$ and the European TED spread measure. We then proceed to re-estimate the model presented in equation (3) using $F e e_{B B_{i, t}}$ as the measure of upfront fees.

\section{[Insert Table 8 about here]}

Results are presented in Table 8. We find that using the two-coupon specification the 'positive upfront fee - CDS spread' relation is even stronger, with both the magnitude and statistical significance of the regression coefficient of the term $F e e_{B B} \times S B$ increasing. On the one hand, this result lends further to support to our central finding that spreads increase with upfront fees. On the other hand, this suggests that the inclusion of an additional two coupons in the European market has had little to no effect on the impact of upfront fees on spreads. ${ }^{27}$

\section{Using the US TED Spread to Capture Funding Costs}

In the main analysis we have computed the upfront fee using the European TED spread measure, following the findings of Cerutti et al. (2017) indicating that the European TED spread measure is a better measure capturing cross-border bank flows outside of the GFC, compared to its US based measures. However, much of the funding of global banks is obtained in US dollars. ${ }^{28}$ Consequently, we re-estimate our results from Section IV, using the US TED

\footnotetext{
${ }^{27}$ The addition of the two additional fixed coupon rates (25bps and 1000bps) in the Small Bang compared to the Big Bang had as primary purpose the improvement of liquidity in the European CDS market, by allowing a greater reduction in the upfront fees that need to be exchanged between parties.

${ }^{28}$ This is true even for some non-US global banks, albeit less so for European banks (see Aldasoro, Ehlers, and Eren (2019)).
} 
spread, measured as the difference between the 3-month USD Libor rate and the 3-month US Treasury yield.

Results are presented in the appendix in tables A2 - A5. We find qualitatively similar results to the prior analysis, with the statistical significance generally improving, with the estimates of the point coefficients of the variables capturing the effect of the upfront fee on CDS spreads being up to three times larger in some specifications. In conclusion, we document that CDS spreads increase with the fee irrespective of the funding currency.

\section{Conclusions}

The CDS Small Bang reforms have improved standardization in the European CDS market. However, since the adoption of the reforms, the cross-sectional average level of CDS spreads has been higher than the average pre-crisis level, even after accounting for the crisis episodes that took place. Looking at the specific features of the reforms, one of the primary regulatory changes introduced was the standardization of coupons. Specifically, in order to standardize the cash flow of CDS contracts the reform has introduced an upfront fee needing to be exchanged between market participants that engage in transacting CDS contracts. We document that the adoption of this new rule has had unintended consequences.

Using data on single-name investment grade constituents of the Markit iTraxx Europe index between January 2006 and December 2019, we show that the introduction of upfront fees has created a market trading environment that is more capital intensive. This, in turn, has had the effect of widening CDS spreads. Moreover, we document that this effect is asymmetric and dependent on whether the buyer or seller of credit protection pays the fee and on whether dealers are on aggregate net CDS buyer or sellers. To this end, we show that during the postSmall Bang sample period, major dealers have been on aggregate net protection buyers. In accord with this, we find that CDS spreads increase particularly when the protection buyer pays 
the upfront fee. We also document that the relationship between upfront fees and CDS spreads is industry dependent. We evidence that the relationship is positive and significant following the Small Bang reforms for all industries, except for contracts written on financial entities, potentially indicating that the standardization benefits clearly outweigh the downsides when trading CDSs on these reference entities. Finally, we conduct a series of robustness tests. To this end, we find that our results are replicated at the market level using cross-sectional averages of our variables, that results are replicated if market participants use only the two fixed coupons (100bps and 500bps) introduced in the Big Bang reforms, instead of the four coupons introduced in the European CDS market, and that results are robust to choosing a funding cost measure based on the US market, instead of the European market.

Our research highlights the complexities of standardization reforms aimed at standardizing highly heterogeneous contracts, traditionally exchanged in bilateral OTC transactions. In the specific case of CDS, we show that the introduction of an upfront payment needed to standardize the cash flow of the contracts has increased the funding costs for dealers in this segment of the OTC market. Does this additional capital charge affect dealers' ability to engage in market making activity in CDS? We show that it makes CDS trading more expensive, as it has increased CDS prices. It remains to be seen whether the benefits of the centralization of trading and clearing encouraged by the greater contract standardization will outweigh this additional cost and improve market functioning and financial stability. Episodes of liquidity fragility and price dislocation in key financial markets have highlighted the importance of dealers for the smooth and efficient operation of financial markets. 


\section{References}

Acharya, V.V., and A. Bisin. "Counterparty Risk Externality: Centralized Versus Over-theCounter Markets.” Journal of Economic Theory, 149 (2014), 153-182.

Acharya, V.V.; T. Eisert; C. Eufinger; and C. Hirsch. "Real Effects of the Sovereign Debt Crisis in Europe: Evidence from Syndicated Loans." The Review of Financial Studies, 31 (2018), 2855-2896.

Acharya, V.V.; T. Eisert; C. Eufinger; and C. Hirsch. "Whatever It Takes: The Real Effects of Unconventional Monetary Policy.” The Review of Financial Studies, 32 (2019), 3366-3411.

Adrian, T.; E. Etula; and T. Muir. "Financial Intermediaries and the Cross-Section of Asset Returns." Journal of Finance, 69 (2014), 2557-2596.

Aldasoro, I., and T. Ehlers. "The Credit Default Swap Market: What a Difference a Decade Makes.” BIS Quarterly Review, 6 (2018), 1-14.

Aldasoro, I.; T. Ehlers; and E. Eren. "Global Banks, Dollar Funding, and Regulation", BIS Working Paper, Bank for International Settlements, (2019).

Alexander, C., and A. Kaeck. "Regime Dependent Determinants of Credit Default Swap Spreads." Journal of Banking and Finance, 32 (2008), 1008-1021.

Anderson, M. "What Drives the Commonality between Credit Default Swap Spread Changes?" Journal of Financial and Quantitative Analysis, 52 (2017), 243-275.

Annaert, J.; M. De Ceuster; P. Van Roy; and C. Vespro. "What Determines Euro Area Bank CDS Spreads?" Journal of International Money and Finance, 32 (2013), 444-461.

Arora, N.; P. Gandhi; and F.A. Longstaff. "Counterparty Credit Risk and the Credit Default Swap Market.” Journal of Financial Economics, 103 (2012), 280 - 293.

Atkeson, A.G.; A.L. Eisfeldt; and P-O. Weill. "The Market for OTC Derivatives" Working Paper, NBER, (2013).

Augustin, P.; M.G. Subrahmanyam; Tang, D. Y.; and S.Q. Wang. "Credit Default Swaps: A Survey". Foundations and Trends in Finance, 9 (2014), 1-196.

Berndt, A., and I. Obreja. "Decomposing European CDS returns." Review of Finance, 14 (2010), 189-233.

Bolton, P., and M. Oehmke. "Strategic Conduct in Credit Derivative Markets." International Journal of Industrial Organization, 31 (2013), 652-658.

Breitenfellner, B., and N. Wagner. "Explaining Aggregate Credit Default Swap Spreads." International Review of Financial Analysis, 22 (2010), 18-29.

Brunnermeier, M.K., and L.H. Pedersen. "Market Liquidity and Funding Liquidity." Review of Financial Studies, 22 (2009), 2201-2238.

Callsen, G., and A. Hill. "The European Corporate Single Name Credit Default Swap Market." Working Paper, ICMA Zurich (2018).

Cerutti, E.; S. Claessens; and L. Ratnovski. "Global Liquidity and Cross-Border Bank Flows", Economic Policy, 32 (2017), 81-125

Corò, F.; A. Dufour; and S. Varotto. "Credit and Liquidity Components of Corporate CDS Spreads." Journal of Banking and Finance, 37 (2013), 5511-5525. 
Danis, A. "Do Empty Creditors Matter? Evidence from Distressed Exchange Offers." Management Science, 63 (2017), 1285-1301.

Daures-Lescourret, L., and A. Fulop. "Standardization, Transparency Initiatives and Liquidity in the CDS Market.” Working Paper, ESSEC Business School (2021)

De Haan, J., and R. Vlahu. "Corporate Governance of Banks: A Survey." Journal of Economic Surveys, 30 (2016), 228-277.

Duan, J-C., and T. Wang. "Measuring Distance-to-Default for Financial and Non-Financial Firms." Global Credit Review, 2 (2012), 95-108.

Duffie, D., and H. Zhu. "Does a Central Clearing Counterparty Reduce Counterparty Risk?" Review of Asset Pricing Studies, 1 (2011), 74-95.

Duffie, D.; M. Scheicher; and G. Vuillemey. "Central Clearing and Collateral Demand." Journal of Financial Economics, 116 (2015), 237-256.

Ericsson, J.; K. Jacobs; and R. Oviedo. "The Determinants of Credit Default Swap Premia", Journal of Financial and Quantitative Analysis, 44 (2009), 109-132.

ECB. "Credit Default Swaps and Counterparty Risk." European Central Bank, Germany, (2009).

FSB. "Review of OTC derivatives market reforms - Effectiveness and broader effects of the reforms." Financial Stability Board, (2017).

Galil, K.; O.M. Shapir; D. Amiram; and U. Ben-Zion. "The Determinants of CDS Spreads." Journal of Banking and Finance, 41 (2014), 271-282.

Gelpern, A., and M. Gulati. "CDS Zombies” European Business Organization Law Review, 13 (2012), 347-390.

Gündüz, Y.; S. Ongena; G. Tümer-Alkan; and Yu, Y. "CDS and Credit: After the Bangs, Cheaper Credit Insurance, More Lending and Hedging” Working Paper, (2020).

He, Z.; B. Kelly; and A. Manela. "Intermediary Asset Pricing: New Evidence from Many Asset Classes." Journal of Financial Economics, 126 (2017), 1-35.

He, Z., and A. Krishnamurthy. "Intermediary Asset Pricing." American Economic Review, 103 (2013), 732-770.

Hui, C-H.; C-F. Lo; and C-S. Lau. "Option-Implied Correlation Between iTraxx Europe Financials and Non-Financials Indexes: A Measure of Spillover Effect in European Debt Crisis." Journal of Banking and Finance, 37 (2013), 3694-3703.

IMF. "Making Over-the-Counter Derivatives Safer: The Role of Central Counterparties", Global Financial Stability Report, International Monetary Fund, (2010).

IMF. "Improving the balance between financial and economic risk taking." Global Financial Stability Report, International Monetary Fund, (2014).

IMF. "Fragilities in the U.S. Treasury Market: Lessons from the "Flash Rally" of October 15, 2014”, IMF Working Paper, 222 (2015a).

IMF. “Market liquidity - resilient or fleeting?”, Global Financial Stability Report, International Monetary Fund, (2015b). 
Junge, B., and A.B. Trolle. "Liquidity Risk in Credit Default Swap Markets." Working Paper, Swiss Finance Institute (2015).

Loon, Y.C., and Z. Zhong. "The Impact of Central Clearing on Counterparty Risk, Liquidity and Trading: Evidence from the Credit Default Swap Market." Journal of Financial Economics, 112 (2014), 91-115.

Loon, Y.C., and Z. Zhong. "Does Dodd-Frank Affect OTC Transaction Costs and Liquidity? Evidence from Real-Time CDS Trade Reports." Journal of Financial Economics, 119 (2016), 645-672.

McBride, P.M. "The Dodd-Frank Act and OTC Derivatives: The Impact of Mandatory Central Clearing on the Global OTC Derivatives Market." The International Lawyer, 44 (2010), 1077 1122.

Narayanan, R., and C. Uzmanoglu. "Credit Default Swaps and Firm Value", Journal of Financial and Quantitative Analysis, 53 (2018), 1227-1259.

Oehmke, M., and A. Zawadowski. "The Anatomy of the CDS Market." Review of Financial Studies, 30 (2016), 80-119.

Peltonen, T.A.; M. Scheicher; and G. Vuillemey. "The Network Structure of the CDS Market and its Determinants." Journal of Financial Stability, 13 (2014), 118-133.

Pires, P.; J.P. Pereira; and L.F. Martins. "The Empirical Determinants of Credit Default Swap Spreads: A Quantile Regression Approach.” European Financial Management, 21 (2015), 556-589.

Silva, P.P.; C. Vieira; and I. Vieira. "The EU Ban on Uncovered Sovereign Credit Default Swaps: Assessing Impacts on Liquidity, Volatility, and Price Discovery." Journal of Derivatives, 23 (2016), 74-98.

Sidanius, C., and F. Zikes. "OTC Derivatives Reform and Collateral Demand Impact", Working Paper, Bank of England (2012).

Siriwardane, E.N. "Limited Investment Capital and Credit Spreads." Journal of Finance, 74 (2019), 2303-2347.

Stulz, R. M. "Credit Default Swaps and the Credit Crisis." Journal of Economic Perspectives, 24 (2010), 73-92.

Tang, D.Y., and H. Yan. "Market Conditions, Default Risk, and Credit Spreads." Journal of Banking and Finance, 34 (2010), 724-734.

Tang, D.Y., and H. Yan. "Understanding Transactions Prices in Credit Default Swaps Market", Journal of Financial Markets, 32 (2017), 1-27.

Vause, N. "Counterparty Risk and Contract Volumes in the Credit Default Swap Market" BIS Quarterly Review, 12 (2010), 59-69.

Wang, X.; Y. Wu; H. Yan; and Z. Zhong. "Funding Liquidity Shocks in a Quasi-Experiment: Evidence from the CDS Big Bang”. Journal of Financial Economics, 139 (2021), 545-560. 
Figure 1: CDS Spreads - A Short-Term and a Long-Term View

Figure 1 plots average monthly CDS spreads. Graph A plots average spreads across the whole sample (January 2006 - December 2019). Graph B displays spreads in the period 6-month prior to 6-month after the CDS Small Bang event (January 2009 - December 2009). Spreads represent end-of-month values and are averaged across entities. The grey vertical line indicates the month when the Small Bang reforms were enacted (June 2009). The grey horizontal line from Graph A represents the average CDS spread observed in the pre-GFC period (January 2006 - March 2007). Data is obtained from Bloomberg.

Graph A: Average CDS Spread Levels - Long-Term View

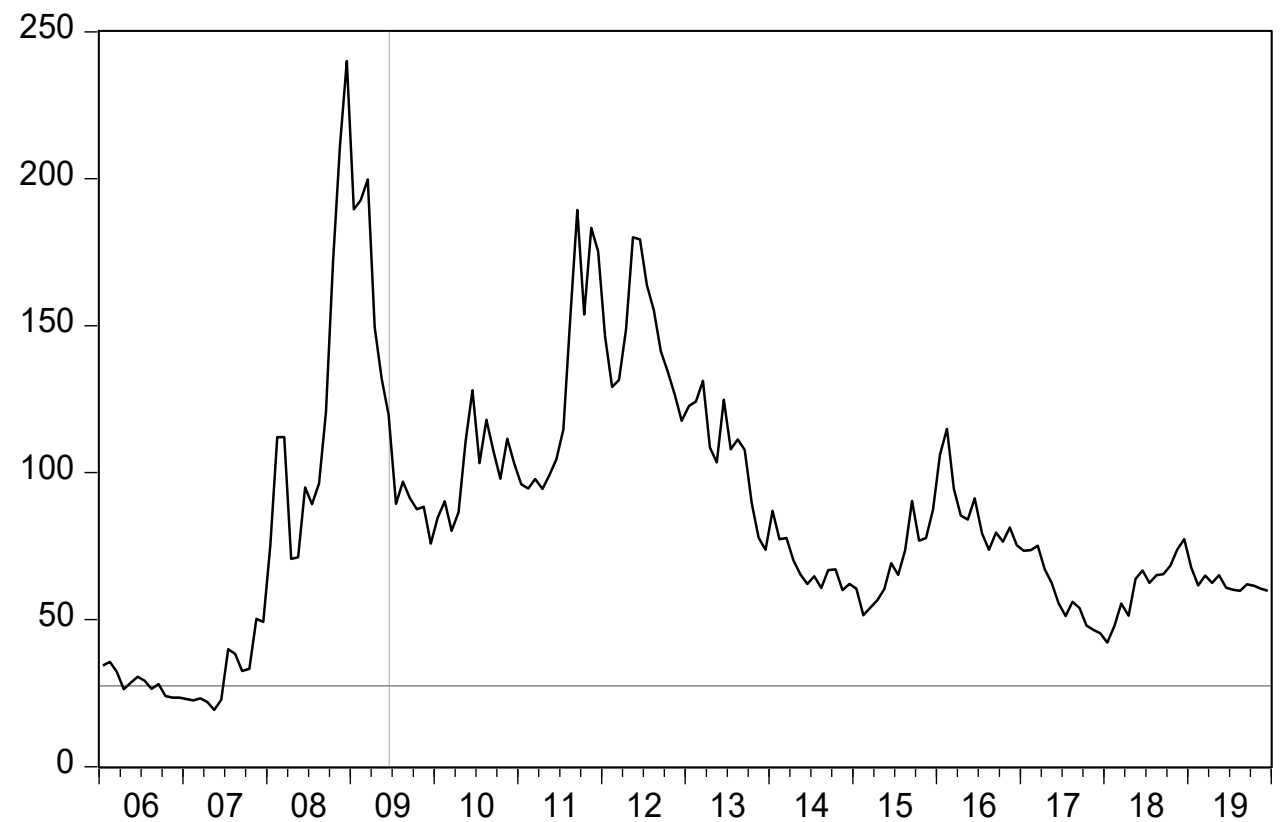

Graph B: Average CDS Spread Levels around the Small Bang

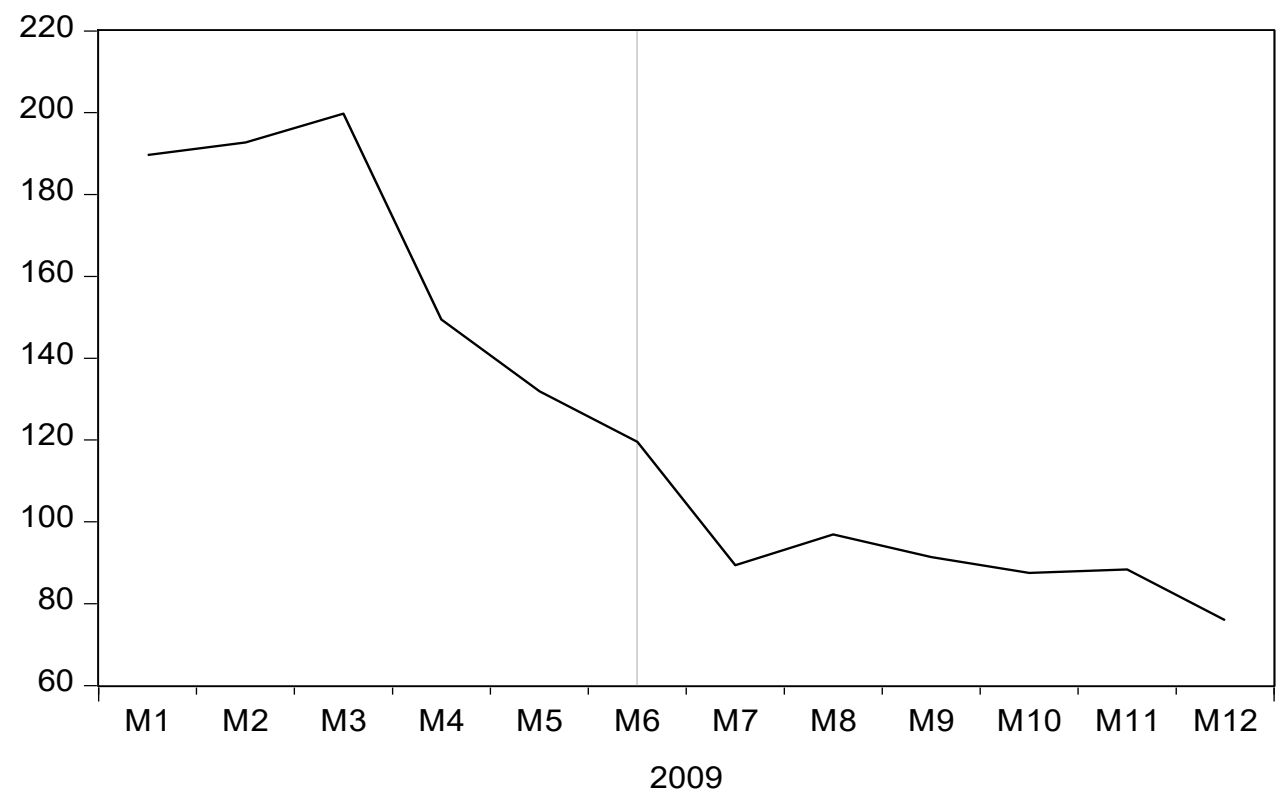


Figure 2: CDS Bid-Ask Spreads - A Short-Term and a Long-Term View

Figure 2 plots average monthly CDS bid-ask spreads. Graph A plots average bid-ask spreads across the whole sample (January 2006 - December 2019). Graph B displays bid-ask spreads in the period 6-month prior to 6-month after the CDS Small Bang event (January 2009 December 2009). Bid-ask spreads represent end-of-month values and are averaged across entities. The grey vertical line indicates the month when the Small Bang reforms were introduced (June 2009). The grey horizontal line from Graph A represents the average CDS bid-ask spread observed in the pre-GFC period (January 2006 - March 2007). Data is obtained from Bloomberg.

Graph A: Average CDS Bid-Ask Spread - Long-Term View

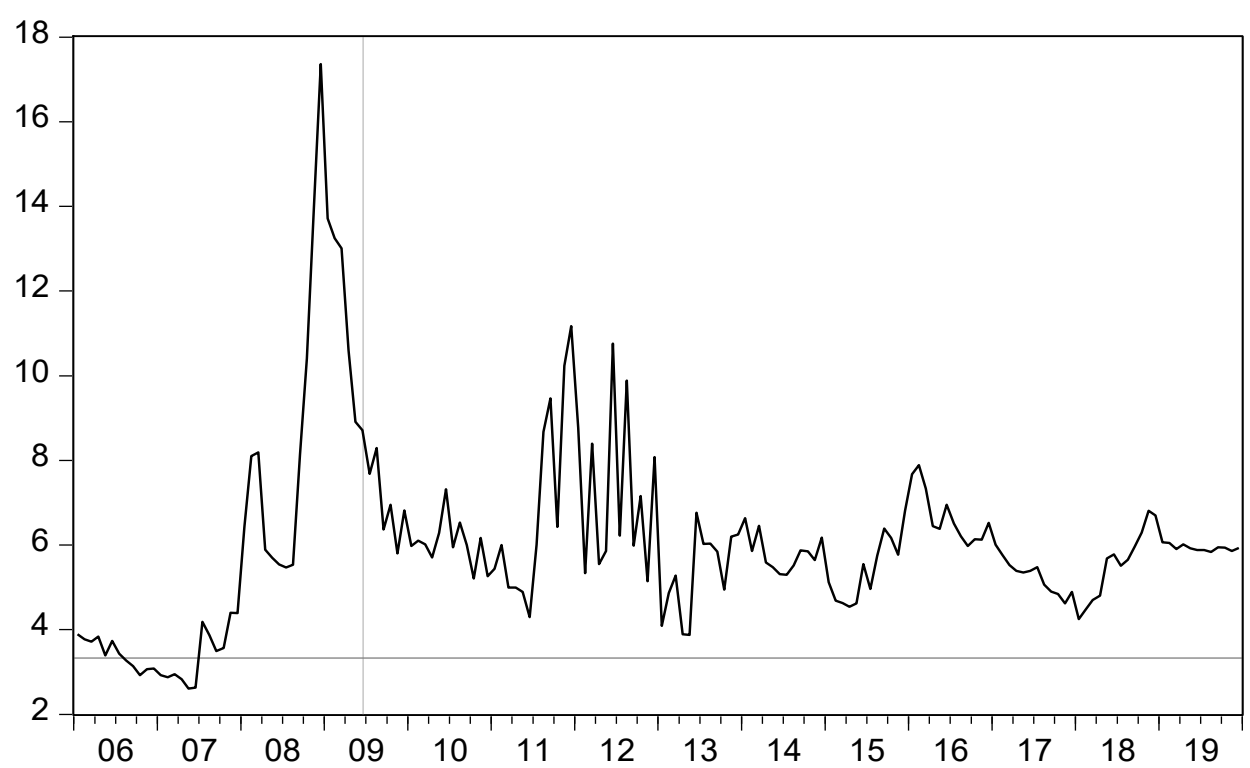

Graph B: Average CDS Bid-Ask Spread around the Small Bang

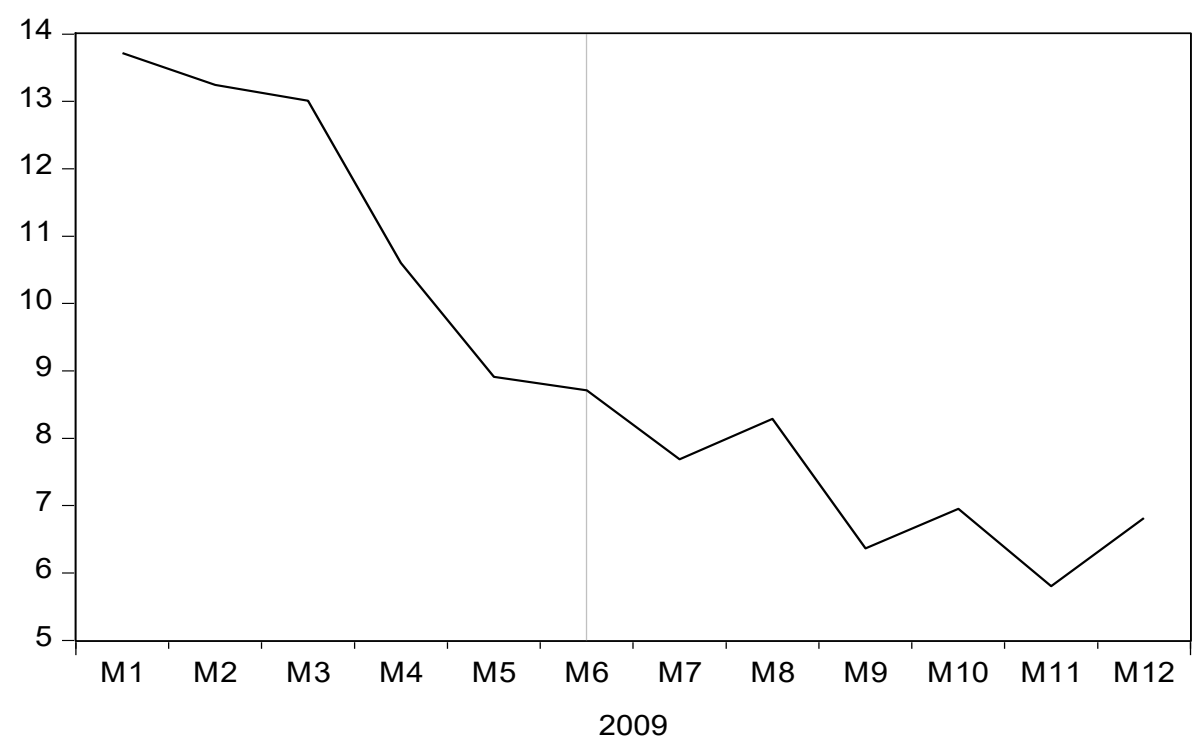




\section{Figure 3: CDS Market Concentration}

Figure 3 plots aggregate total notional amounts of CDSs bought and sold by four major dealers in the CDS market (Morgan Stanley, Goldman Sachs, JP Morgan, and Citigroup) as a proportion of total notional amounts of CDSs bought and sold. Amounts of CDSs bought and sold by dealers are obtained from TIW of DTCC and Group Annual Reports. Aggregate notional amounts of CDS bought and sold are obtained from the BIS.

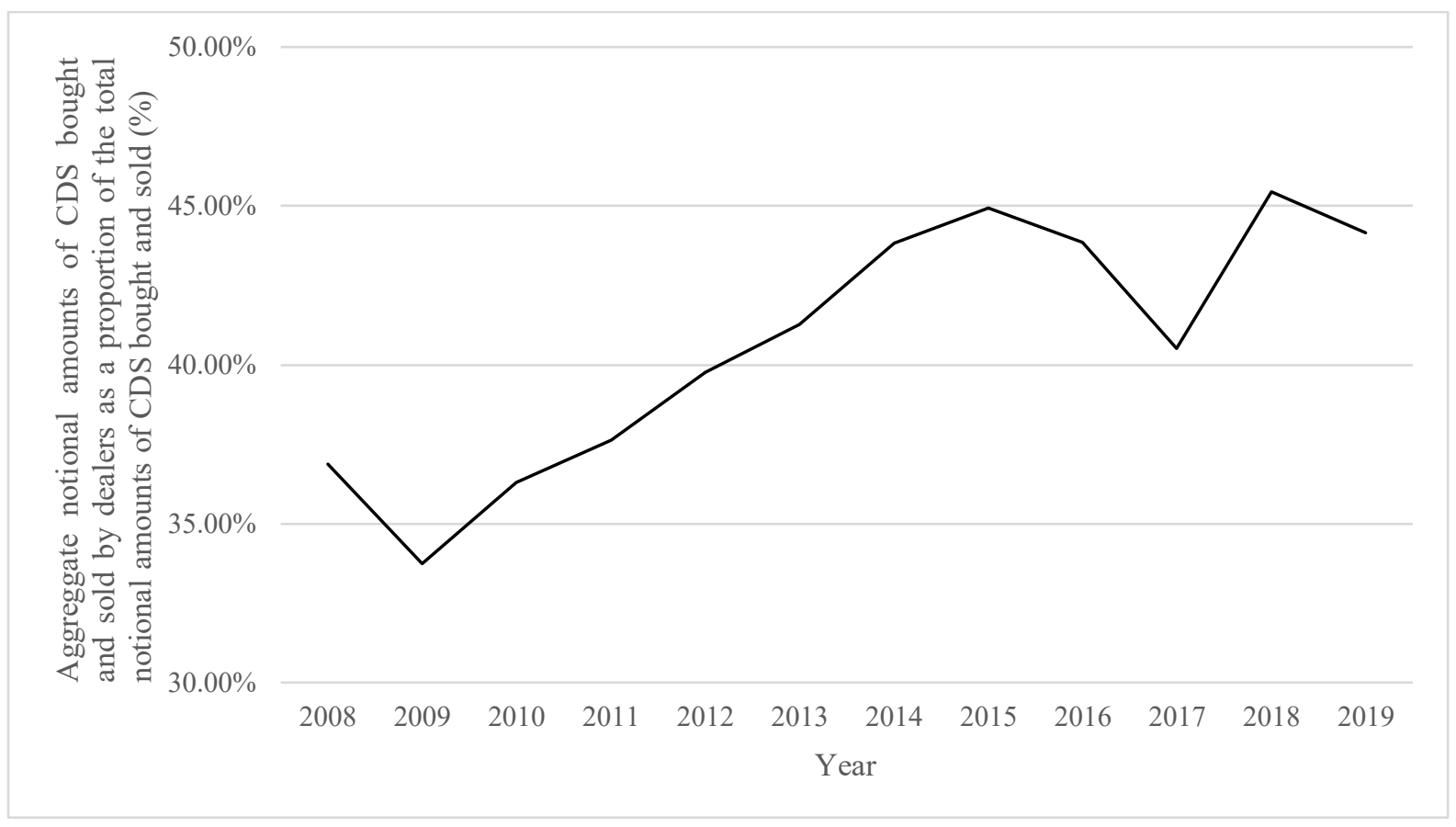


Figure 4: Evolution of Upfront Fee Over Time

Figure 4 presents the monthly cross-sectional average upfront fee (in bps) exchanged between the parties involved in the CDS transaction over time. The fee is calculated as shown in equation (2). The data span is the post-Small Bang period (June 2009 - December 2019).

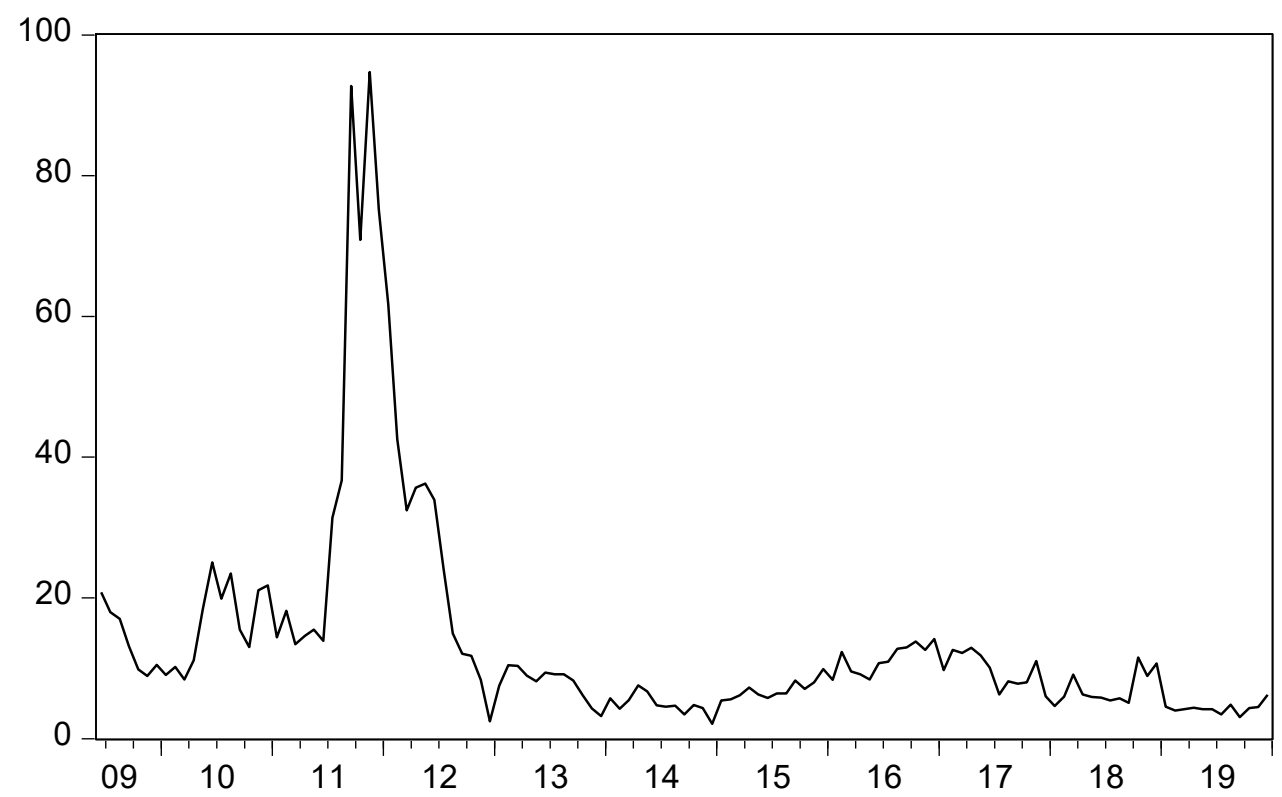




\section{Table 1 - Major CDS Dealer Aggregate Positions}

Table 1 reports the aggregate amounts of CDS protection purchased and written, as well as corresponding gross and net total aggregate amounts of CDS transacted of the four large CDS dealers (Morgan Stanley, Goldman Sachs, JP Morgan and Citigroup) between 2008 and 2019. The last column represents the total net amount of protection transacted as a proportion of the total amounts of protection bought and sold. Aggregate notional amounts are expressed in USD billions. Data is obtained from the TIW reports, the DTCC and Group Annual Reports.

\begin{tabular}{c|cccc|c} 
Year & $\begin{array}{c}\text { Protection purchased } \\
(1)\end{array}$ & $\begin{array}{c}\text { Protection written } \\
(2)\end{array}$ & $\begin{array}{c}\text { Total } \\
(1)+(2)\end{array}$ & $\begin{array}{c}\text { Net } \\
(1)-(2)\end{array}$ & Net / Total \\
\hline 2008 & 13556.70 & 12905.82 & 26462.52 & 650.88 & $2.46 \%$ \\
2009 & 9519.41 & 9141.12 & 18660.53 & 378.28 & $2.03 \%$ \\
2010 & 8517.72 & 8221.47 & 16739.19 & 296.26 & $1.77 \%$ \\
2011 & 8857.48 & 8624.87 & 17482.35 & 232.61 & $1.33 \%$ \\
2012 & 8109.38 & 7954.03 & 16063.41 & 155.36 & $0.97 \%$ \\
2013 & 6732.96 & 6578.63 & 13311.59 & 154.33 & $1.16 \%$ \\
2014 & 5405.15 & 5240.59 & 10645.74 & 164.56 & $1.55 \%$ \\
2015 & 4093.82 & 3939.72 & 8033.54 & 154.10 & $1.92 \%$ \\
2016 & 3070.07 & 2934.10 & 6004.17 & 135.97 & $2.26 \%$ \\
2017 & 2414.25 & 2315.51 & 4729.76 & 98.73 & $2.09 \%$ \\
2018 & 2333.08 & 2188.16 & 4521.24 & 144.92 & $3.21 \%$ \\
2019 & 2079.23 & 1894.76 & 3973.99 & 184.48 & $4.64 \%$
\end{tabular}


Table 2 - Summary Statistics

Table 2 presents summary statistics of the dataset. Panel A presents the summary statistics of our whole sample of 104 European investment-grade companies from January 2006 to December 2019. Panel B presents the summary statistics for the period preceding the Small Bang reforms from January 2006 to May 2009. Panel C presents the summary statistics of our sample in the period following the Small Bang reforms, from June 2009 to December 2019. $C D S$ spread is the midpoint of the bid and ask quotes of the CDS spreads (in bps). DIS is the minimum difference, in absolute terms, between the CDS spread and the four possible coupon rates (in bps). TED spread is the difference between the 3-month Euribor rate and the 3-month German Government BuBill (in \%). CDS bid-ask spread is the difference between the ask and bid quotes of the CDS spreads (in bps). CDS volatility is the 30-day historical volatility of CDS spreads (in bps). Stock return is the monthly stock return (in \%). Scaled stock bid-ask spread is the difference between the ask and bid quotes of the stock divided by their midpoint. Stock volatility is the 30-day historical volatility of stock returns (in \%). 10-year risk-free rate is the yield on the 10-year Euro-area Government bond. Slope Yield is the difference between the 10year and 2-year Euro-area Government bond yields. Implied Volatility is the level of the VSTOXX implied volatility index. Fee is the size of the upfront payment defined as the product between DIS and TED spread. Scaled Fee is the size of the upfront payment divided by the CDS spread. Data is collected from Bloomberg.

Panel A: Whole Sample (January 2006 to December 2019)

\begin{tabular}{lcccccc}
\hline Variable & Mean & Median & Max & Min & Std. Dev. & N \\
\hline CDS spread & 85.989 & 66.463 & 1380.453 & 3.417 & 75.302 & 17375 \\
DIS & 29.324 & 22.322 & 380.453 & 0.000 & 32.390 & 17375 \\
TED spread & 0.460 & 0.344 & 2.824 & 0.020 & 0.421 & 17472 \\
CDS bid-ask spread & 6.056 & 5.088 & 101.982 & 0.000 & 3.920 & 17375 \\
CDS volatility & 45.849 & 38.810 & 1006.920 & 4.060 & 29.238 & 17302 \\
Stock return & 0.060 & 0.429 & 67.711 & -73.129 & 7.881 & 17359 \\
Scaled stock bid-ask spread & 0.001 & 0.001 & 0.187 & -0.045 & 0.004 & 17463 \\
Stock volatility & 27.680 & 23.673 & 401.482 & 2.754 & 15.911 & 17462 \\
10-year risk-free rate & 0.019 & 0.017 & 0.046 & -0.007 & 0.015 & 17472 \\
Slope Yield & 0.010 & 0.011 & 0.022 & 0.000 & 0.006 & 17472 \\
Implied Volatility & 22.433 & 20.391 & 60.677 & 11.986 & 8.012 & 17472 \\
\hline
\end{tabular}


Panel B: Pre-Small Bang Sample (January 2006 to May 2009)

\begin{tabular}{lcccccc}
\hline Variable & Mean & Median & Max & Min & Std. Dev. & $\mathrm{N}$ \\
\hline CDS spread & 75.395 & 45.688 & 1380.453 & 3.417 & 97.038 & 4167 \\
TED spread & 0.659 & 0.514 & 2.824 & 0.020 & 0.718 & 4264 \\
CDS bid-ask spread & 5.965 & 4.095 & 101.982 & 0.000 & 5.733 & 4167 \\
CDS volatility & 61.779 & 53.235 & 1006.920 & 4.060 & 41.734 & 4112 \\
Stock return & -0.997 & -0.147 & 67.711 & -73.129 & 9.641 & 4151 \\
Scaled stock bid-ask spread & 0.001 & 0.001 & 0.037 & -0.029 & 0.002 & 4255 \\
Stock volatility & 34.192 & 26.842 & 401.482 & 4.683 & 23.769 & 4254 \\
10-year risk-free rate & 0.039 & 0.040 & 0.046 & 0.030 & 0.004 & 4264 \\
Slope Yield & 0.005 & 0.004 & 0.022 & 0.000 & 0.006 & 4264 \\
Implied Volatility & 24.862 & 19.992 & 60.677 & 14.014 & 11.410 & 4264 \\
\hline
\end{tabular}

Panel C: Post-Small Bang Sample (June 2009 to December 2019)

\begin{tabular}{lcccccc}
\hline Variable & Mean & Median & Max & Min & Std. Dev. & $\mathrm{N}$ \\
\hline CDS spread & 89.332 & 70.555 & 1148.227 & 14.719 & 66.653 & 13208 \\
Fee & 13.604 & 7.493 & 273.868 & 0.000 & 23.453 & 13208 \\
Scaled Fee & 0.135 & 0.113 & 0.916 & 0.000 & 0.112 & 13208 \\
DIS & 30.294 & 24.513 & 223.600 & 0.001 & 31.107 & 13208 \\
TED spread & 0.396 & 0.336 & 1.377 & 0.057 & 0.224 & 13208 \\
CDS bid-ask spread & 6.085 & 5.295 & 77.104 & 0.288 & 3.138 & 13208 \\
CDS volatility & 40.883 & 36.840 & 284.510 & 5.100 & 21.788 & 13190 \\
Stock return & 0.393 & 0.591 & 52.368 & -62.481 & 7.208 & 13208 \\
Scaled stock bid-ask spread & 0.001 & 0.001 & 0.187 & -0.045 & 0.005 & 13208 \\
Stock volatility & 25.582 & 23.025 & 139.188 & 2.754 & 11.607 & 13208 \\
10-year risk-free rate & 0.012 & 0.009 & 0.034 & -0.007 & 0.011 & 13208 \\
Slope Yield & 0.012 & 0.012 & 0.022 & 0.002 & 0.005 & 13208 \\
Implied Volatility & 21.649 & 20.599 & 46.680 & 11.986 & 6.354 & 13208 \\
\hline
\end{tabular}




\section{Table 3 - The Effect of the Upfront Fee on CDS Spreads}

Table 3 presents the impact of the upfront fees brought about by the CDS Small Bang on CDS spreads. Column (1) presents results for the determinants of CDS spreads without the inclusion of the upfront fee. Column (2) presents results of the effect of the upfront fee on CDS spreads using the whole sample (January 2006 - December 2009). Column (3) presents results of the effect of the upfront fee on CDS spreads in the post-Small Bang sample (June 2009 - December 2019). Column (4) presents results of the effect of the upfront fee between the Small Bang event and the end of the European Debt Crisis (June 2009 - July 2012). Column (5) presents results of the effect of the upfront fee after the European Debt Crisis (August 2012 - December 2019). The dependent variable in all models is the first difference of CDS spreads $(\triangle C D S$ spread $) . * *, * *$, and * denote significance at the $1 \%, 5 \%$, and $10 \%$ levels, respectively. All estimations are carried out using firm fixed effects and standard errors clustered by firm. Data is collected from Bloomberg for the period January 2006 - December 2019.

\begin{tabular}{|c|c|c|c|c|c|}
\hline $\begin{array}{c}\text { Sample: } \\
\text { Period }\end{array}$ & $\begin{array}{l}\text { Whole sample } \\
\text { Jan06-Dec19 } \\
\text { (1) }\end{array}$ & $\begin{array}{l}\text { Whole Sample } \\
\text { Jan06-Dec19 } \\
\text { (2) }\end{array}$ & $\begin{array}{l}\text { Post-Small Bang } \\
\text { June09-Dec19 } \\
\text { (3) }\end{array}$ & $\begin{array}{c}\text { Small Bang - Debt Crisis } \\
\text { June09-July12 } \\
\text { (4) }\end{array}$ & $\begin{array}{c}\text { Post-Debt Crisis } \\
\text { Aug12-Dec19 } \\
\text { (5) }\end{array}$ \\
\hline Constant & $\begin{array}{c}-0.13 \\
{[-0.20]}\end{array}$ & $\begin{array}{c}-0.10 \\
{[-0.16]}\end{array}$ & $\begin{array}{c}-0.17 \\
{[-0.29]}\end{array}$ & $\begin{array}{c}1.68 \\
{[1.35]}\end{array}$ & $\begin{array}{c}-0.68 \\
{[-1.21]}\end{array}$ \\
\hline Return & $\begin{array}{c}-0.72 * * * \\
{[-7.19]}\end{array}$ & $\begin{array}{c}-0.71 * * * \\
{[-8.13]}\end{array}$ & $\begin{array}{c}-0.77 * * * \\
{[-8.64]}\end{array}$ & $\begin{array}{c}-0.99 * * * \\
{[-5.75]}\end{array}$ & $\begin{array}{c}-0.60 * * * \\
{[-7.74]}\end{array}$ \\
\hline$\Delta$ Stock volatility & $\begin{array}{c}0.21 * * * \\
{[2.91]}\end{array}$ & $\begin{array}{c}0.17 * * * \\
{[2.95]}\end{array}$ & $\begin{array}{l}0.10 * * \\
{[2.06]}\end{array}$ & $\begin{array}{c}0.05 \\
{[0.53]}\end{array}$ & $\begin{array}{l}0.12 * * \\
{[2.51]}\end{array}$ \\
\hline$\triangle C D S$ volatility & $\begin{array}{c}0.04 * * * \\
{[2.60]}\end{array}$ & $\begin{array}{l}0.04 * * \\
{[2.46]}\end{array}$ & $\begin{array}{c}0.11 * * * \\
{[4.49]}\end{array}$ & $\begin{array}{c}0.13 * * * \\
{[3.19]}\end{array}$ & $\begin{array}{c}0.08 * * * \\
{[3.54]}\end{array}$ \\
\hline$\Delta$ Stock bid-ask & $\begin{array}{c}0.10 \\
{[0.15]}\end{array}$ & $\begin{array}{c}-0.12 \\
{[-0.18]}\end{array}$ & $\begin{array}{c}0.12 \\
{[0.20]}\end{array}$ & $\begin{array}{c}0.00 \\
{[0.00]}\end{array}$ & $\begin{array}{c}0.20 \\
{[0.53]}\end{array}$ \\
\hline$\triangle C D S$ bid-ask & $\begin{array}{c}3.90 * * * \\
{[6.86]}\end{array}$ & $\begin{array}{c}3.62 * * * \\
{[6.44]}\end{array}$ & $\begin{array}{c}2.36 * * * \\
{[5.58]}\end{array}$ & $\begin{array}{c}2.36 * * * \\
{[4.68]}\end{array}$ & $\begin{array}{c}2.62 * * * \\
{[4.57]}\end{array}$ \\
\hline$\Delta$ Risk-free rate & $\begin{array}{c}-12.12 * * \\
{[-2.16]}\end{array}$ & $\begin{array}{c}-11.31 * * \\
{[-1.96]}\end{array}$ & $\begin{array}{c}-4.77 \\
{[-0.82]}\end{array}$ & $\begin{array}{c}2.46 \\
{[0.33]}\end{array}$ & $\begin{array}{c}3.48 \\
{[0.35]}\end{array}$ \\
\hline$\Delta$ Slope yield & $\begin{array}{c}-1.79 \\
{[-0.22]}\end{array}$ & $\begin{array}{c}-2.09 \\
{[-0.28]}\end{array}$ & $\begin{array}{c}1.07 \\
{[0.13]}\end{array}$ & $\begin{array}{c}-2.82 \\
{[-0.31]}\end{array}$ & $\begin{array}{c}-3.50 \\
{[-0.28]}\end{array}$ \\
\hline$\triangle V S T O X X$ & $\begin{array}{c}0.56 * * * \\
{[2.83]}\end{array}$ & $\begin{array}{l}0.41 * * \\
{[2.20]}\end{array}$ & $\begin{array}{c}0.66^{* * *} * \\
{[4.45]}\end{array}$ & $\begin{array}{c}1.35 * * * \\
{[4.42]}\end{array}$ & $\begin{array}{l}0.31 * * \\
{[2.36]}\end{array}$ \\
\hline$\Delta F e e$ & & $\begin{array}{l}0.12 * * \\
{[2.57]}\end{array}$ & $\begin{array}{c}0.28 * * * \\
{[4.46]}\end{array}$ & $\begin{array}{c}0.18 * * * \\
{[2.70]}\end{array}$ & $\begin{array}{c}0.74 * * * \\
{[4.92]}\end{array}$ \\
\hline$\Delta F e e \times S B$ & & $\begin{array}{r}0.14 * \\
{[1.96]}\end{array}$ & & & \\
\hline $\begin{array}{l}\text { Observations: } \\
\text { R-squared: }\end{array}$ & $\begin{array}{c}17188 \\
0.38\end{array}$ & $\begin{array}{c}17188 \\
0.41\end{array}$ & $\begin{array}{c}13189 \\
0.40\end{array}$ & $\begin{array}{l}3933 \\
0.46\end{array}$ & $\begin{array}{c}9256 \\
0.39\end{array}$ \\
\hline
\end{tabular}




\section{Table 4 - Asymmetric Effects of the Small Bang Upfront Fee}

Table 4 presents the asymmetric effect of the upfront fee on CDS spreads dependent on whether the protection buyer or seller pays the upfront fee. Column (1) presents results estimating the effect of the buyer paying the fee using the whole time-series sample. Column (2) presents results of the asymmetric effect of the buyer paying the upfront fee on CDS spreads in the post-Small Bang sample (June 2009 - December 2019), while Columns (3) and (4) present these results between the Small Bang event and the end of the European Debt Crisis (EDC) (June 2009 - July 2012), and after the European Debt Crisis (August 2012 - December 2019), respectively. The dependent variable in all models is the first difference of CDS spreads ( $\triangle C D S$ spread). All estimations are carried out using firm fixed effects and standard errors clustered by firm. Data is collected from Bloomberg for the period January 2006 - December 2019.

\begin{tabular}{|c|c|c|c|c|}
\hline $\begin{array}{l}\text { Sample: } \\
\text { Period }\end{array}$ & $\begin{array}{l}\text { Whole Sample } \\
\text { Jan06-Dec19 } \\
\text { (1) }\end{array}$ & $\begin{array}{l}\text { Post-Small Bang } \\
\text { June09-Dec19 } \\
\text { (2) }\end{array}$ & $\begin{array}{c}\text { Small Bang - Debt Crisis } \\
\text { June09-July12 } \\
\text { (3) }\end{array}$ & $\begin{array}{l}\text { Post-Debt Crisis } \\
\text { Aug12-Dec19 } \\
\text { (4) }\end{array}$ \\
\hline Constant & $\begin{array}{c}-0.11 \\
{[-0.20]}\end{array}$ & $\begin{array}{c}-0.15 \\
{[-0.31]}\end{array}$ & $\begin{array}{c}1.37 \\
{[1.32]}\end{array}$ & $\begin{array}{c}-0.46 \\
{[-1.04]}\end{array}$ \\
\hline Return & $\begin{array}{c}-0.65^{* * *} \\
{[-7.60]}\end{array}$ & $\begin{array}{c}-0.67 * * * \\
{[-8.27]}\end{array}$ & $\begin{array}{c}-0.82 * * * \\
{[-4.94]}\end{array}$ & $\begin{array}{c}-0.51 * * * \\
{[-6.66]}\end{array}$ \\
\hline$\Delta$ Stock volatility & $\begin{array}{l}0.15^{* *} \\
{[2.57]}\end{array}$ & $\begin{array}{l}0.10^{* *} \\
{[2.45]}\end{array}$ & $\begin{array}{c}0.07 \\
{[0.91]}\end{array}$ & $\begin{array}{l}0.09 * * \\
{[2.17]}\end{array}$ \\
\hline$\triangle C D S$ volatility & $\begin{array}{c}0.04 * * * \\
{[2.64]}\end{array}$ & $\begin{array}{c}0.09 * * * \\
{[4.00]}\end{array}$ & $\begin{array}{c}0.11 * * * \\
{[3.09]}\end{array}$ & $\begin{array}{c}0.06^{* * *} \\
{[2.75]}\end{array}$ \\
\hline$\Delta$ Stock bid-ask & $\begin{array}{c}-0.15 \\
{[-0.23]}\end{array}$ & $\begin{array}{c}0.17 \\
{[0.31]}\end{array}$ & $\begin{array}{c}0.14 \\
{[0.10]}\end{array}$ & $\begin{array}{c}0.20 \\
{[0.59]}\end{array}$ \\
\hline$\triangle C D S$ bid-ask & $\begin{array}{c}3.38^{* * *} \\
{[6.91]}\end{array}$ & $\begin{array}{c}2.13 * * * \\
{[5.66]}\end{array}$ & $\begin{array}{l}2.08 * * * \\
{[4.55]}\end{array}$ & $\begin{array}{c}2.33 * * * \\
{[4.97]}\end{array}$ \\
\hline$\Delta 10$-year risk-free rate & $\begin{array}{c}-10.02 * * \\
{[-2.03]}\end{array}$ & $\begin{array}{c}-4.00 \\
{[-0.82]}\end{array}$ & $\begin{array}{c}-0.30 \\
{[-0.05]}\end{array}$ & $\begin{array}{c}3.73 \\
{[0.49]}\end{array}$ \\
\hline$\Delta$ Slope yield & $\begin{array}{c}-1.40 \\
{[-0.20]}\end{array}$ & $\begin{array}{c}0.58 \\
{[0.09]}\end{array}$ & $\begin{array}{c}-1.86 \\
{[-0.26]}\end{array}$ & $\begin{array}{c}-3.88 \\
{[-0.41]}\end{array}$ \\
\hline$\triangle V S T O X X$ & $\begin{array}{l}0.35^{* *} \\
{[2.16]}\end{array}$ & $\begin{array}{c}0.49 * * * \\
{[3.85]}\end{array}$ & $\begin{array}{l}1.00 * * * \\
{[3.76]}\end{array}$ & $\begin{array}{c}0.18^{*} \\
{[1.70]}\end{array}$ \\
\hline$\Delta F e e$ & $\begin{array}{c}-0.06 \\
{[-0.63]}\end{array}$ & $\begin{array}{c}-0.64 * * * \\
{[-2.79]}\end{array}$ & $\begin{array}{c}-0.54 * * \\
{[-2.52]}\end{array}$ & $\begin{array}{c}-1.41 * * * \\
{[-6.78]}\end{array}$ \\
\hline$\Delta F e e \times$ Buyer & $\begin{array}{l}0.27^{* *} \\
{[2.10]}\end{array}$ & $\begin{array}{c}1.17 * * * \\
{[3.83]}\end{array}$ & $\begin{array}{c}0.94 * * * \\
{[3.31]}\end{array}$ & $\begin{array}{l}2.74^{* * * *} \\
{[8.89]}\end{array}$ \\
\hline$\Delta F e e \times$ Buyer $\times S B$ & $\begin{array}{l}0.28^{* * * *} \\
{[2.72]}\end{array}$ & & & \\
\hline $\begin{array}{c}\text { Observations: } \\
R \text {-sauared. }\end{array}$ & $\begin{array}{c}17188 \\
045\end{array}$ & $\begin{array}{c}13189 \\
048\end{array}$ & $\begin{array}{r}3933 \\
054\end{array}$ & 9256 \\
\hline R-squared: & 0.45 & 0.48 & 0.54 & 0.50 \\
\hline
\end{tabular}


Table 5 - Impact of Upfront Fee on CDS Spreads - Distinguishing Between Financial and

\section{Non-Financial Firms}

Table 5 presents results highlighting the asymmetric effects of the exchange of upfront fees on CDS spreads written on financial and non-financial companies. Columns (1) and (2) explore the effects of the upfront fees on CDS spreads of financial entities for the whole time-series sample (January 2006 - December 2019) and post-Small Bang sample (June 2009 - December 2019), respectively. Columns (3) and (4) explore the effects of the upfront fees on CDS spreads of non-financial entities for the whole time-series sample and post-Small Bang sample, respectively. All estimations are carried out using firm fixed effects and standard errors clustered by firm. Data is collected from Bloomberg for the period January 2006 - December 2019.

\begin{tabular}{|c|c|c|c|c|}
\hline $\begin{array}{l}\text { Sample of firms } \\
\text { Sample Period }\end{array}$ & $\begin{array}{c}\text { Financial } \\
\text { Whole Sample } \\
\text { (1) }\end{array}$ & $\begin{array}{c}\text { Financial } \\
\text { Post-Small Bang } \\
\text { (2) }\end{array}$ & $\begin{array}{l}\text { Non-Financial } \\
\text { Whole Sample } \\
\text { (3) }\end{array}$ & $\begin{array}{c}\text { Non-Financial } \\
\text { Post-Small Bang } \\
\text { (4) }\end{array}$ \\
\hline Constant & $\begin{array}{c}-0.21 * * * \\
{[-6.08]}\end{array}$ & $\begin{array}{c}-0.16^{* * *} \\
{[-3.72]}\end{array}$ & $\begin{array}{c}-0.10^{* * *} \\
{[-2.82]}\end{array}$ & $\begin{array}{c}-0.13 * * * \\
{[-2.68]}\end{array}$ \\
\hline Return & $\begin{array}{c}-0.79 * * * \\
{[-6.92]}\end{array}$ & $\begin{array}{c}-0.94 * * * \\
{[-9.15]}\end{array}$ & $\begin{array}{c}-0.71 * * * \\
{[-8.89]}\end{array}$ & $\begin{array}{c}-0.69 * * * \\
{[-5.86]}\end{array}$ \\
\hline$\Delta$ Stock volatility & $\begin{array}{c}0.00 \\
{[0.04]}\end{array}$ & $\begin{array}{c}-0.02 \\
{[-0.29]}\end{array}$ & $\begin{array}{l}0.21 * * * \\
{[6.45]}\end{array}$ & $\begin{array}{l}0.13 * * * \\
{[5.14]}\end{array}$ \\
\hline$\triangle C D S$ volatility & $\begin{array}{l}0.04 * * \\
{[2.54]}\end{array}$ & $\begin{array}{l}0.11 * * * \\
{[5.05]}\end{array}$ & $\begin{array}{c}0.04 * * * \\
{[2.72]}\end{array}$ & $\begin{array}{l}0.11 * * * \\
{[3.95]}\end{array}$ \\
\hline$\Delta$ Stock bid-ask & $\begin{array}{l}-1.07^{*} \\
{[-1.74]}\end{array}$ & $\begin{array}{c}-0.81 \\
{[-1.35]}\end{array}$ & $\begin{array}{c}0.39 \\
{[0.72]}\end{array}$ & $\begin{array}{c}0.48 \\
{[0.87]}\end{array}$ \\
\hline$\triangle C D S$ bid-ask & $\begin{array}{l}2.97 * * * \\
{[11.60]}\end{array}$ & $\begin{array}{l}2.36^{* * *} \\
{[10.70]}\end{array}$ & $\begin{array}{l}3.82 * * * \\
{[10.76]}\end{array}$ & $\begin{array}{c}2.35^{* * * *} \\
{[4.83]}\end{array}$ \\
\hline$\Delta 10$-year risk-free rate & $\begin{array}{c}-6.06^{* * *} \\
{[-3.35]}\end{array}$ & $\begin{array}{c}-11.98 * * * \\
{[-4.58]}\end{array}$ & $\begin{array}{c}-12.46^{* * *} \\
{[-7.77]}\end{array}$ & $\begin{array}{l}-3.42 * * \\
{[-2.09]}\end{array}$ \\
\hline$\Delta$ Slope yield & $\begin{array}{c}-8.84 * * * \\
{[-3.53]}\end{array}$ & $\begin{array}{c}23.10^{* * *} \\
{[4.81]}\end{array}$ & $\begin{array}{c}-0.59 \\
{[-0.41]}\end{array}$ & $\begin{array}{l}-4.20^{*} \\
{[-1.74]}\end{array}$ \\
\hline$\triangle V S T O X X$ & $\begin{array}{l}0.96^{* * *} \\
{[5.62]}\end{array}$ & $\begin{array}{l}1.52 * * * \\
{[6.78]}\end{array}$ & $\begin{array}{l}0.32 * * * \\
{[4.52]}\end{array}$ & $\begin{array}{l}0.43 * * * \\
{[4.54]}\end{array}$ \\
\hline$\Delta F e e$ & $\begin{array}{l}0.17 * * * \\
{[3.39]}\end{array}$ & $\begin{array}{c}0.06 \\
{[0.58]}\end{array}$ & $\begin{array}{l}0.14 * * * \\
{[5.15]}\end{array}$ & $\begin{array}{l}0.37 * * * \\
{[5.51]}\end{array}$ \\
\hline $\begin{array}{l}\text { Observations: } \\
\text { R-squared: }\end{array}$ & $\begin{array}{l}3340 \\
0.43\end{array}$ & $\begin{array}{l}2520 \\
0.47\end{array}$ & $\begin{array}{c}13848 \\
0.41\end{array}$ & $\begin{array}{c}10566 \\
0.41\end{array}$ \\
\hline
\end{tabular}


Table 6 - Impact of the Upfront Fee on CDS Spreads - Differences Across Industry Sectors

Table 6 presents the impact of the upfront fees brought about by the CDS Small Bang on CDS spreads across five different industry sectors, using the specification presented in Eq. (6). Column (1) presents results of the effect of the upfront fee on CDS spreads using the whole sample (January 2006 - December 2009). Column (2) presents results of the effect of the upfront fee on CDS spreads in the post-Small Bang sample (June 2009 - December 2019). Column (3) presents results of the effect of the upfront fee between the Small Bang event and the end of the European Debt Crisis (June 2009 - July 2012). Column (4) presents results of the effect of the upfront fee after the European Debt Crisis (August 2012 - December 2019). The dependent variable in all models is the first difference of CDS spreads ( $\triangle C D S$ spread). All estimations are carried out using firm fixed effects and standard errors clustered by firm. Data is collected from Bloomberg for the period January 2006 - December 2019.

\begin{tabular}{|c|c|c|c|c|}
\hline $\begin{array}{c}\text { Sample: } \\
\text { Period }\end{array}$ & $\begin{array}{l}\text { Whole Sample } \\
\text { Jan06-Dec19 } \\
\text { (1) }\end{array}$ & $\begin{array}{l}\text { Post-Small Bang } \\
\text { June09-Dec19 } \\
\text { (2) }\end{array}$ & $\begin{array}{c}\text { Small Bang - Debt Crisis } \\
\text { June09-July12 } \\
\text { (3) }\end{array}$ & $\begin{array}{l}\text { Post-Debt Crisis } \\
\text { Aug12-Dec19 } \\
\text { (4) }\end{array}$ \\
\hline Constant & $\begin{array}{c}-0.11 \\
{[-0.18]}\end{array}$ & $\begin{array}{c}-0.16 \\
{[-0.28]}\end{array}$ & $\begin{array}{c}1.69 \\
{[1.38]}\end{array}$ & $\begin{array}{c}-0.68 \\
{[-1.21]}\end{array}$ \\
\hline Return & $\begin{array}{c}-0.73 * * * \\
{[-8.57]}\end{array}$ & $\begin{array}{c}-0.77 * * * \\
{[-8.64]}\end{array}$ & $\begin{array}{c}-0.99 * * * \\
{[-5.73]}\end{array}$ & $\begin{array}{c}-0.60 * * * \\
{[-7.69]}\end{array}$ \\
\hline$\Delta$ Stock volatility & $\begin{array}{c}0.16^{* * *} \\
{[2.99]}\end{array}$ & $\begin{array}{l}0.11 * * \\
{[2.25]}\end{array}$ & $\begin{array}{c}0.08 \\
{[0.84]}\end{array}$ & $\begin{array}{l}0.12 * * \\
{[2.53]}\end{array}$ \\
\hline$\triangle C D S$ volatility & $\begin{array}{l}0.04 * * \\
{[2.48]}\end{array}$ & $\begin{array}{c}0.11 * * * \\
{[4.43]}\end{array}$ & $\begin{array}{c}0.13 * * * \\
{[3.02]}\end{array}$ & $\begin{array}{c}0.08 * * * \\
{[3.52]}\end{array}$ \\
\hline$\Delta$ Stock bid-ask & $\begin{array}{c}-0.10 \\
{[-0.16]}\end{array}$ & $\begin{array}{c}0.15 \\
{[0.26]}\end{array}$ & $\begin{array}{c}0.06 \\
{[0.04]}\end{array}$ & $\begin{array}{c}0.21 \\
{[0.53]}\end{array}$ \\
\hline$\Delta C D S$ bid-ask & $\begin{array}{c}3.62 * * * \\
{[6.34]}\end{array}$ & $\begin{array}{c}2.31 * * * \\
{[5.58]}\end{array}$ & $\begin{array}{c}2.28 * * * \\
{[4.72]}\end{array}$ & $\begin{array}{c}2.62 * * * \\
{[4.46]}\end{array}$ \\
\hline$\Delta 10$-year risk-free rate & $\begin{array}{c}-11.31 * \\
{[-1.94]}\end{array}$ & $\begin{array}{c}-4.83 \\
{[-0.84]}\end{array}$ & $\begin{array}{c}2.22 \\
{[0.31]}\end{array}$ & $\begin{array}{c}3.54 \\
{[0.36]}\end{array}$ \\
\hline$\Delta$ Slope yield & $\begin{array}{c}-2.48 \\
{[-0.35]}\end{array}$ & $\begin{array}{c}1.37 \\
{[0.17]}\end{array}$ & $\begin{array}{c}-2.58 \\
{[-0.29]}\end{array}$ & $\begin{array}{c}-3.61 \\
{[-0.29]}\end{array}$ \\
\hline$\triangle V S T O X X$ & $\begin{array}{l}0.45 * * \\
{[2.44]}\end{array}$ & $\begin{array}{c}0.64 * * * \\
{[4.43]}\end{array}$ & $\begin{array}{l}1.30 * * * \\
{[4.47]}\end{array}$ & $\begin{array}{l}0.31 * * \\
{[2.34]}\end{array}$ \\
\hline$\Delta F e e \times I_{\text {Automobile } \& \text { Industrials }}$ & $\begin{array}{l}0.16 * * \\
{[2.35]}\end{array}$ & $\begin{array}{c}0.32 * * * \\
{[4.65]}\end{array}$ & $\begin{array}{c}0.22 * * * \\
{[3.23]}\end{array}$ & $\begin{array}{c}0.72 * * \\
{[2.12]}\end{array}$ \\
\hline$\Delta F e e \times I_{\text {Consumer Products }}$ & $\begin{array}{c}0.09 \\
{[1.36]}\end{array}$ & $\begin{array}{c}0.47 * * * \\
{[6.45]}\end{array}$ & $\begin{array}{c}0.34 * * * \\
{[5.47]}\end{array}$ & $\begin{array}{c}0.88 * * * \\
{[4.75]}\end{array}$ \\
\hline$\Delta F e e \times I_{\text {Energy }}$ & $\begin{array}{l}0.11 \% \\
{[1.78]}\end{array}$ & $\begin{array}{c}0.33 * * * \\
{[2.62]}\end{array}$ & $\begin{array}{l}0.27 * * \\
{[2.15]}\end{array}$ & $\begin{array}{l}0.54 * * \\
{[2.01]}\end{array}$ \\
\hline$\Delta$ Fee $\times I_{\text {Financials }}$ & $\begin{array}{c}0.16 * * * \\
{[3.62]}\end{array}$ & $\begin{array}{c}0.14 \\
{[1.30]}\end{array}$ & $\begin{array}{c}0.04 \\
{[0.38]}\end{array}$ & $\begin{array}{c}0.82 * * * \\
{[5.22]}\end{array}$ \\
\hline$\Delta F e e \times I_{\text {Telecoms, }, \text { Media } \& \text { Tech }}$ & $\begin{array}{c}0.20 * * * \\
{[3.89]}\end{array}$ & $\begin{array}{l}0.25 * * \\
{[2.33]}\end{array}$ & $\begin{array}{c}0.14 \\
{[1.21]}\end{array}$ & $\begin{array}{c}0.58 * * * \\
{[2.59]}\end{array}$ \\
\hline $\begin{array}{l}\text { Observations: } \\
\text { R-squared: }\end{array}$ & $\begin{array}{c}17188 \\
0.41\end{array}$ & $\begin{array}{c}13189 \\
0.41\end{array}$ & $\begin{array}{r}3933 \\
0.47\end{array}$ & $\begin{array}{l}9256 \\
0.39\end{array}$ \\
\hline
\end{tabular}




\section{Table 7 - Impact of the Upfront Fee on CDS Spreads - Market-wide Analysis}

Table 7 presents the impact of the upfront fees brought about by the CDS Small Bang on CDS spreads at the aggregate (market) level. The time-series regression specification is presented in Eq. (7). Column (1) presents results of the effect of the upfront fee on CDS spreads using the whole sample (January 2006 - December 2009). Column (2) presents results of the effect of the upfront fee on CDS spreads in the post-Small Bang sample (June 2009 - December 2019). Column (3) presents results of the effect of the upfront fee between the Small Bang event and the end of the European Debt Crisis (June 2009 - July 2012). Column (4) presents results of the effect of the upfront fee after the European Debt Crisis (August 2012 - December 2019). The dependent variable in all models is the first difference in the market-wide average CDS spread ( $\triangle$ Market CDS spread). All estimations are carried out using heteroskedasticity and autocorrelation consistent HAC standard errors. Data is collected from Bloomberg for the period January 2006 - December 2019.

\begin{tabular}{|c|c|c|c|c|}
\hline $\begin{array}{l}\text { Sample: } \\
\text { Period }\end{array}$ & $\begin{array}{l}\text { Whole Sample } \\
\text { Jan06-Dec19 } \\
\text { (1) }\end{array}$ & $\begin{array}{l}\text { Post-Small Bang } \\
\text { June09-Dec19 } \\
\text { (2) }\end{array}$ & $\begin{array}{c}\text { Small Bang - Debt Crisis } \\
\text { June09-July12 } \\
\text { (3) }\end{array}$ & $\begin{array}{c}\text { Post-Debt Crisis } \\
\text { Aug12-Dec19 } \\
\text { (4) }\end{array}$ \\
\hline Constant & $\begin{array}{c}0.07 \\
{[0.12]}\end{array}$ & $\begin{array}{c}0.06 \\
{[0.11]}\end{array}$ & $\begin{array}{r}1.97 * \\
{[1.92]}\end{array}$ & $\begin{array}{c}-0.57 \\
{[-1.02]}\end{array}$ \\
\hline Market return & $\begin{array}{c}-1.41 * * * \\
{[-5.51]}\end{array}$ & $\begin{array}{c}-1.35 * * * \\
{[-4.84]}\end{array}$ & $\begin{array}{c}-1.85 * * * \\
{[-4.07]}\end{array}$ & $\begin{array}{c}-0.83 * * * \\
{[-3.61]}\end{array}$ \\
\hline$\Delta$ Market stock volatility & $\begin{array}{c}0.21 \\
{[1.23]}\end{array}$ & $\begin{array}{c}0.07 \\
{[0.39]}\end{array}$ & $\begin{array}{c}0.17 \\
{[0.59]}\end{array}$ & $\begin{array}{c}0.06 \\
{[0.35]}\end{array}$ \\
\hline$\triangle$ Market CDS volatility & $\begin{array}{c}-0.03 \\
{[-0.58]}\end{array}$ & $\begin{array}{c}0.06 \\
{[0.96]}\end{array}$ & $\begin{array}{c}-0.06 \\
{[-0.66]}\end{array}$ & $\begin{array}{l}0.14 * * \\
{[2.29]}\end{array}$ \\
\hline$\Delta$ Market stock bid-ask & $\begin{array}{c}0.42 \\
{[0.04]}\end{array}$ & $\begin{array}{c}2.22 \\
{[0.37]}\end{array}$ & $\begin{array}{c}-4.34 \\
{[-0.67]}\end{array}$ & $\begin{array}{c}5.09 \\
{[0.66]}\end{array}$ \\
\hline$\Delta$ Market CDS bid-ask & $\begin{array}{c}3.43 * * * \\
{[4.58]}\end{array}$ & $\begin{array}{l}1.74 * * * \\
{[3.37]}\end{array}$ & $\begin{array}{l}2.18 * * * \\
{[3.74]}\end{array}$ & $\begin{array}{l}1.92 * * * \\
{[2.67]}\end{array}$ \\
\hline$\Delta$ Risk-free rate & $\begin{array}{c}-7.15 \\
{[-1.45]}\end{array}$ & $\begin{array}{c}-1.76 \\
{[-0.34]}\end{array}$ & $\begin{array}{c}4.32 \\
{[0.64]}\end{array}$ & $\begin{array}{c}2.84 \\
{[0.33]}\end{array}$ \\
\hline$\Delta$ Slope yield & $\begin{array}{c}-4.21 \\
{[-0.62]}\end{array}$ & $\begin{array}{c}1.29 \\
{[-0.19]}\end{array}$ & $\begin{array}{c}-2.55 \\
{[-0.39]}\end{array}$ & $\begin{array}{c}-1.57 \\
{[-0.14]}\end{array}$ \\
\hline$\triangle V S T O X X$ & $\begin{array}{c}-0.13 \\
{[-0.54]}\end{array}$ & $\begin{array}{c}0.19 \\
{[1.03]}\end{array}$ & $\begin{array}{r}0.69^{*} \\
{[1.71]}\end{array}$ & $\begin{array}{c}0.19 \\
{[1.09]}\end{array}$ \\
\hline$\Delta$ Market Fee & $\begin{array}{l}0.20^{*} \\
{[1.66]}\end{array}$ & $\begin{array}{l}\mathbf{0 . 5 6} 6^{* * *} \\
{[\mathbf{5 . 8 6}]}\end{array}$ & $\begin{array}{l}\mathbf{0 . 3 8}^{* * *} \\
{[3.92]}\end{array}$ & $\begin{array}{l}0.99 * * * \\
{[3.40]}\end{array}$ \\
\hline$\Delta$ Market Fee $\times S B$ & $\begin{array}{l}0.34 * * \\
{[2.38]}\end{array}$ & & & \\
\hline $\begin{array}{l}\text { Observations: } \\
\text { R-squared: }\end{array}$ & $\begin{array}{l}167 \\
0.72\end{array}$ & $\begin{array}{l}127 \\
0.73\end{array}$ & $\begin{array}{c}38 \\
0.88\end{array}$ & $\begin{array}{c}89 \\
0.58\end{array}$ \\
\hline
\end{tabular}




\section{Table 8 - Impact of the Upfront Fee on CDS Spreads - Alternative Coupon Structure}

Table 8 presents the impact of the upfront fees brought about by the CDS Small Bang on CDS spreads if using just two coupons (100bps and 500bps) to derive the upfront fee. The regression specification is the same to that presented in Eq. (3). Column (1) presents results of the effect of the upfront fee on CDS spreads using the whole sample (January 2006 December 2009). Column (2) presents results of the effect of the upfront fee on CDS spreads in the post-Small Bang sample (June 2009 - December 2019). Column (3) presents results of the effect of the upfront fee between the Small Bang event and the end of the European Debt Crisis (June 2009 - July 2012). Column (4) presents results of the effect of the upfront fee after the European Debt Crisis (August 2012 - December 2019). The dependent variable in all models is the first difference of CDS spreads ( $\triangle C D S$ spread). All estimations are carried out using firm fixed effects and standard errors clustered by firm. Data is collected from Bloomberg for the period January 2006 - December 2019.

\begin{tabular}{|c|c|c|c|c|}
\hline $\begin{array}{l}\text { Sample: } \\
\text { Period }\end{array}$ & $\begin{array}{l}\text { Whole Sample } \\
\text { Jan06-Dec19 } \\
\text { (1) }\end{array}$ & $\begin{array}{l}\text { Post-Small Bang } \\
\text { June09-Dec19 } \\
\text { (2) }\end{array}$ & $\begin{array}{c}\text { Small Bang - Debt Crisis } \\
\text { June09-July } 12 \\
\text { (3) }\end{array}$ & $\begin{array}{l}\text { Post-Debt Crisis } \\
\text { Aug12-Dec19 } \\
\text { (4) }\end{array}$ \\
\hline Constant & $\begin{array}{c}-0.11 \\
{[-0.18]}\end{array}$ & $\begin{array}{c}-0.18 \\
{[-0.30]}\end{array}$ & $\begin{array}{c}1.69 \\
{[1.34]}\end{array}$ & $\begin{array}{c}-0.76 \\
{[-1.21]}\end{array}$ \\
\hline Return & $\begin{array}{c}-0.73 * * * \\
{[-8.82]}\end{array}$ & $\begin{array}{c}-0.77 * * * \\
{[-8.89]}\end{array}$ & $\begin{array}{c}-0.99 * * * \\
{[-5.75]}\end{array}$ & $\begin{array}{c}-0.62 * * * \\
{[-9.31]}\end{array}$ \\
\hline$\Delta$ Stock volatility & $\begin{array}{l}0.17 * * * \\
{[2.90]}\end{array}$ & $\begin{array}{l}0.10^{* *} \\
{[2.03]}\end{array}$ & $\begin{array}{c}0.05 \\
{[0.54]}\end{array}$ & $\begin{array}{l}0.12 * * \\
{[2.57]}\end{array}$ \\
\hline$\triangle C D S$ volatility & $\begin{array}{l}0.04 * * \\
{[2.33]}\end{array}$ & $\begin{array}{l}0.11 * * * \\
{[4.61]}\end{array}$ & $\begin{array}{l}0.13 * * * \\
{[3.21]}\end{array}$ & $\begin{array}{l}0.10^{* * *} \\
{[3.70]}\end{array}$ \\
\hline$\Delta$ Stock bid-ask & $\begin{array}{c}-0.14 \\
{[-0.22]}\end{array}$ & $\begin{array}{c}0.09 \\
{[0.14]}\end{array}$ & $\begin{array}{c}-0.07 \\
{[-0.04]}\end{array}$ & $\begin{array}{c}0.16 \\
{[0.40]}\end{array}$ \\
\hline$\triangle C D S$ bid-ask & $\begin{array}{c}3.47 * * * \\
{[7.18]}\end{array}$ & $\begin{array}{l}2.36^{* * *} \\
{[5.78]}\end{array}$ & $\begin{array}{l}2.38 * * * \\
{[4.81]}\end{array}$ & $\begin{array}{l}2.53 * * * \\
{[4.55]}\end{array}$ \\
\hline$\Delta$ Risk-free rate & $\begin{array}{l}-11.35^{*} \\
{[-1.92]}\end{array}$ & $\begin{array}{c}-4.54 \\
{[-0.76]}\end{array}$ & $\begin{array}{c}2.53 \\
{[0.34]}\end{array}$ & $\begin{array}{c}3.21 \\
{[0.29]}\end{array}$ \\
\hline$\Delta$ Slope yield & $\begin{array}{c}-2.06 \\
{[-0.28]}\end{array}$ & $\begin{array}{c}0.73 \\
{[0.09]}\end{array}$ & $\begin{array}{c}-3.21 \\
{[-0.35]}\end{array}$ & $\begin{array}{c}-3.38 \\
{[-0.24]}\end{array}$ \\
\hline$\triangle V S T O X X$ & $\begin{array}{l}0.44 * * \\
{[2.22]}\end{array}$ & $\begin{array}{l}0.68 * * * \\
{[4.64]}\end{array}$ & $\begin{array}{l}1.35^{* * * *} \\
{[4.54]}\end{array}$ & $\begin{array}{l}0.36^{* * *} \\
{[2.59]}\end{array}$ \\
\hline$\Delta F e e_{B B}$ & $\begin{array}{l}0.14 * * * \\
{[4.41]}\end{array}$ & $\begin{array}{l}0.28 * * * \\
{[4.46]}\end{array}$ & $\begin{array}{l}0.19^{* * *} \\
{[2.96]}\end{array}$ & $\begin{array}{c}0.54 * * * \\
{[3.73]}\end{array}$ \\
\hline$\Delta \mathrm{Fee}_{B B} \times S B$ & $\begin{array}{l}0.13 * * \\
{[2.10]}\end{array}$ & & & \\
\hline $\begin{array}{l}\text { Observations: } \\
\text { R-squared: }\end{array}$ & $\begin{array}{c}17188 \\
0.42\end{array}$ & $\begin{array}{c}13189 \\
0.41\end{array}$ & $\begin{array}{l}3933 \\
0.47\end{array}$ & $\begin{array}{c}9256 \\
0.38\end{array}$ \\
\hline
\end{tabular}




\title{
How does standardization affect OTC markets? \\ Evidence from the Small Bang reform in the CDS market
}

\begin{abstract}
APPENDIX
Table A1 - The Effect of the Upfront Fee on CDS Spreads - Alternative specification

Table A1 presents the impact of the upfront fees brought about by the CDS Small Bang on CDS spreads using an alternative specification which includes interaction terms between the Small Bang dummy variable and all independent variables. The estimation specification is: $\Delta C D S_{i, t}=c_{i}+\beta_{1} \Delta F e e_{i, t}+\beta_{2}\left(\Delta F e e_{i, t} \times S B_{t}\right)+\gamma_{1}\left(\Delta X_{i, t} \times S B_{t}\right)+$ $\gamma_{2}\left(\Delta Y_{t} \times S B_{t}\right)+u_{i}+\varepsilon_{i, t}$ Column (1) presents results for the determinants of CDS spreads without the inclusion of the upfront fee. Column (2) presents results of the effect of the upfront fee on CDS spreads using the whole sample (January 2006 - December 2009). Column (3) presents results of the effect of the upfront fee on CDS spreads in the post-Small Bang sample (June 2009 - December 2019). Column (4) presents results of the effect of the upfront fee between the Small Bang event and the end of the European Debt Crisis (June 2009 - July 2012). Column (5) presents results of the effect of the upfront fee after the European Debt Crisis (August 2012 - December 2019). ***,**, and * denote significance at the $1 \%, 5 \%$ and $10 \%$ levels, respectively. The dependent variable in all models is the first difference of CDS spreads ( $\triangle C D S$ spread). All estimations are carried out using firm fixed effects and standard errors clustered by firm. Data is collected from Bloomberg for the period January 2006 - December 2019.
\end{abstract}




\begin{tabular}{|c|c|c|}
\hline $\begin{array}{l}\text { Sample: } \\
\text { Period }\end{array}$ & $\begin{array}{c}\text { Whole sample } \\
\text { Jan06-Dec19 } \\
(1) \\
\end{array}$ & $\begin{array}{c}\text { Whole Sample } \\
\text { Jan06-Dec19 } \\
(2) \\
\end{array}$ \\
\hline Constant & $\begin{array}{c}0.12 \\
{[0.20]}\end{array}$ & $\begin{array}{c}0.14 \\
{[0.25]}\end{array}$ \\
\hline Return & $\begin{array}{c}-0.56 * * * \\
{[-3.58]}\end{array}$ & $\begin{array}{c}-0.58 * * * \\
{[-4.00]}\end{array}$ \\
\hline$\Delta$ Stock volatility & $\begin{array}{c}0.29 * * * \\
{[2.78]}\end{array}$ & $\begin{array}{l}0.25 * * \\
{[2.51]}\end{array}$ \\
\hline$\triangle C D S$ volatility & $\begin{array}{c}-0.00 \\
{[-0.21]}\end{array}$ & $\begin{array}{c}-0.00 \\
{[-0.26]}\end{array}$ \\
\hline$\Delta$ Stock bid-ask & $\begin{array}{c}-2.20 \\
{[-1.14]}\end{array}$ & $\begin{array}{l}-2.68 \\
{[-1.58]}\end{array}$ \\
\hline$\triangle C D S$ bid-ask & $\begin{array}{c}6.41^{* * *} \\
{[7.95]}\end{array}$ & $\begin{array}{c}6.02 * * * \\
{[6.88]}\end{array}$ \\
\hline$\Delta$ Risk-free rate & $\begin{array}{c}-16.52 * * \\
{[-2.19]}\end{array}$ & $\begin{array}{c}-16.79 * * \\
{[-2.27]}\end{array}$ \\
\hline$\Delta$ Slope yield & $\begin{array}{c}-8.01 \\
{[-0.71]}\end{array}$ & $\begin{array}{c}-6.03 \\
{[-0.59]}\end{array}$ \\
\hline$\triangle V S T O X X$ & $\begin{array}{c}0.37 \\
{[1.01]}\end{array}$ & $\begin{array}{c}0.19 \\
{[0.53]}\end{array}$ \\
\hline$\Delta F e e$ & & $\begin{array}{l}0.09 * * \\
{[2.39]}\end{array}$ \\
\hline Return $\times S B$ & $\begin{array}{c}-0.25 \\
{[-1.37]}\end{array}$ & $\begin{array}{c}-0.19 \\
{[-1.10]}\end{array}$ \\
\hline$\Delta$ Stock volatility $\times S B$ & $\begin{array}{c}-0.18 \\
{[-1.49]}\end{array}$ & $\begin{array}{c}-0.14 * * * \\
{[-1.31]}\end{array}$ \\
\hline$\triangle C D S$ volatility $\times S B$ & $\begin{array}{c}0.12 * * * \\
{[3.83]}\end{array}$ & $\begin{array}{c}0.12 * * * \\
{[3.82]}\end{array}$ \\
\hline$\Delta$ Stock bid-ask $\times S B$ & $\begin{array}{c}2.46 \\
{[1.21]}\end{array}$ & $\begin{array}{c}2.79 \\
{[1.55]}\end{array}$ \\
\hline$\triangle C D S$ bid-ask $\times S B$ & $\begin{array}{c}-3.89 * * * \\
{[-4.25]}\end{array}$ & $\begin{array}{c}-3.67 * * * \\
{[-3.77]}\end{array}$ \\
\hline$\Delta$ Risk-free rate $\times S B$ & $\begin{array}{c}9.70 \\
{[1.01]}\end{array}$ & $\begin{array}{l}12.43 \\
{[1.31]}\end{array}$ \\
\hline$\Delta$ Slope yield $\times S B$ & $\begin{array}{c}12.38 \\
{[0.86]}\end{array}$ & $\begin{array}{c}6.92 \\
{[0.53]}\end{array}$ \\
\hline$\triangle V S T O X X \times S B$ & $\begin{array}{c}0.42 \\
{[1.03]}\end{array}$ & $\begin{array}{c}0.47 \\
{[1.21]}\end{array}$ \\
\hline$\Delta F e e \times S B$ & & $\begin{array}{c}0.19 * * * \\
{[2.58]}\end{array}$ \\
\hline $\begin{array}{l}\text { Observations: } \\
\text { R-squared: } \\
\end{array}$ & $\begin{array}{c}17188 \\
0.42 \\
\end{array}$ & $\begin{array}{c}17188 \\
0.45 \\
\end{array}$ \\
\hline
\end{tabular}




\section{Table A2 - The Effect of the Upfront Fee on CDS Spreads}

Table A2 presents the impact of the upfront fees brought about by the CDS Small Bang on CDS spreads. The upfront fee (Fee $\left.e_{U S}\right)$ is calculated as in Equation (2) but using the US TED spread (3-month USD Libor - 3-month T-bill rate). The US TED spread is collected from FRED. Column (1) presents results for the determinants of CDS spreads without the inclusion of the upfront fee. Column (2) presents results of the effect of the upfront fee on CDS spreads using the whole sample (January 2006 December 2009). Column (3) presents results of the effect of the upfront fee on CDS spreads in the post-Small Bang sample (June 2009 - December 2019). Column (4) presents results of the effect of the upfront fee between the Small Bang event and the end of the European Debt Crisis (June 2009 - July 2012). Column (5) presents results of the effect of the upfront fee after the European Debt Crisis (August 2012 - December 2019). ***, **, and * denote significance at the 1\%, 5\% and 10\% levels, respectively. The dependent variable in all models is the first difference of CDS spreads ( $\triangle C D S$ spread). All estimations are carried out using firm fixed effects and standard errors clustered by firm. Data is collected from Bloomberg for the period January 2006 - December 2019.

Sample: $\quad$ Whole sample Whole Sample Post-Small Bang Small Bang-Debt Crisis Post-Debt Crisis Period Jan06-Dec19 Jan06-Dec19 June09-Dec19 June09-July12 Aug12-Dec19

(1)

(2)

(4)

(5)

\begin{tabular}{|c|c|c|c|c|c|}
\hline Constant & $\begin{array}{c}-0.13 \\
{[-0.20]}\end{array}$ & $\begin{array}{c}-0.09 \\
{[-0.14]}\end{array}$ & $\begin{array}{c}-0.16 \\
{[-0.27]}\end{array}$ & $\begin{array}{c}1.75 \\
{[1.36]}\end{array}$ & $\begin{array}{c}-0.76 \\
{[-1.28]}\end{array}$ \\
\hline Return & $\begin{array}{c}-0.72 * * * \\
{[-7.19]}\end{array}$ & $\begin{array}{c}-0.68 * * * \\
{[-7.25]}\end{array}$ & $\begin{array}{c}-0.73 * * * \\
{[-8.48]}\end{array}$ & $\begin{array}{c}-0.95 * * * \\
{[-5.85]}\end{array}$ & $\begin{array}{c}-0.61 * * * \\
{[-7.40]}\end{array}$ \\
\hline$\Delta$ Stock volatility & $\begin{array}{c}0.21 * * * \\
{[2.91]}\end{array}$ & $\begin{array}{c}0.17 * * * \\
{[2.61]}\end{array}$ & $\begin{array}{r}0.09 * \\
{[1.75]}\end{array}$ & $\begin{array}{c}0.01 \\
{[0.12]}\end{array}$ & $\begin{array}{c}0.14 * * * \\
{[2.62]}\end{array}$ \\
\hline$\triangle C D S$ volatility & $\begin{array}{c}0.04 * * * \\
{[2.60]}\end{array}$ & $\begin{array}{l}0.04 * * \\
{[2.23]}\end{array}$ & $\begin{array}{c}0.11 * * * \\
{[4.40]}\end{array}$ & $\begin{array}{c}0.13^{* * *} \\
{[3.08]}\end{array}$ & $\begin{array}{c}0.08 * * * \\
{[3.12]}\end{array}$ \\
\hline$\Delta$ Stock bid-ask & $\begin{array}{c}0.10 \\
{[0.15]}\end{array}$ & $\begin{array}{c}-0.08 \\
{[-0.12]}\end{array}$ & $\begin{array}{c}0.06 \\
{[0.09]}\end{array}$ & $\begin{array}{c}-0.05 \\
{[-0.03]}\end{array}$ & $\begin{array}{c}0.12 \\
{[0.33]}\end{array}$ \\
\hline$\Delta C D S$ bid-ask & $\begin{array}{c}3.90 * * * \\
{[6.86]}\end{array}$ & $\begin{array}{c}3.67 * * * \\
{[6.42]}\end{array}$ & $\begin{array}{c}2.30 * * * \\
{[5.26]}\end{array}$ & $\begin{array}{c}2.37 * * * \\
{[4.70]}\end{array}$ & $\begin{array}{c}2.35 * * * \\
{[3.48]}\end{array}$ \\
\hline$\Delta$ Risk-free rate & $\begin{array}{c}-12.12 * * \\
{[-2.16]}\end{array}$ & $\begin{array}{c}-12.35^{* *} \\
{[-2.09]}\end{array}$ & $\begin{array}{c}-6.18 \\
{[-1.13]}\end{array}$ & $\begin{array}{c}2.42 \\
{[0.34]}\end{array}$ & $\begin{array}{c}-0.77 \\
{[-0.07]}\end{array}$ \\
\hline$\Delta$ Slope yield & $\begin{array}{c}-1.79 \\
{[-0.22]}\end{array}$ & $\begin{array}{c}-1.76 \\
{[-0.21]}\end{array}$ & $\begin{array}{c}2.32 \\
{[0.30]}\end{array}$ & $\begin{array}{c}-2.77 \\
{[-0.31]}\end{array}$ & $\begin{array}{c}1.09 \\
{[0.07]}\end{array}$ \\
\hline$\triangle V S T O X X$ & $\begin{array}{c}0.56 * * * \\
{[2.83]}\end{array}$ & $\begin{array}{l}0.47 * * \\
{[2.43]}\end{array}$ & $\begin{array}{c}0.73 * * * \\
{[4.30]}\end{array}$ & $\begin{array}{l}1.46^{* * *} \\
{[4.89]}\end{array}$ & $\begin{array}{l}0.35 * * \\
{[2.43]}\end{array}$ \\
\hline$\Delta \boldsymbol{F e e}_{U S}$ & & $\begin{array}{l}0.09 * * \\
{[2.34]}\end{array}$ & $\begin{array}{c}0.58 * * * \\
{[4.79]}\end{array}$ & $\begin{array}{l}0.41 * * * \\
{[2.58]}\end{array}$ & $\begin{array}{c}0.67 * * * \\
{[3.89]}\end{array}$ \\
\hline$\Delta \mathrm{Fee}_{U S} \times S B$ & & $\begin{array}{c}0.44 * * * \\
{[3.75]}\end{array}$ & & & \\
\hline $\begin{array}{l}\text { Observations: } \\
\text { R-squared: }\end{array}$ & $\begin{array}{c}17188 \\
0.38\end{array}$ & $\begin{array}{c}17188 \\
0.40\end{array}$ & $\begin{array}{c}13189 \\
0.40\end{array}$ & $\begin{array}{c}3933 \\
0.46\end{array}$ & $\begin{array}{c}9256 \\
0.38\end{array}$ \\
\hline
\end{tabular}




\section{Table A3 - Asymmetric Effects of the Small Bang Upfront Fee}

Table A3 presents the asymmetric effect of the upfront fee on CDS spreads dependent on whether the protection buyer or seller pays the upfront fee. The upfront fee is calculated as in Equation (2) but using the US TED spread (3-month USD Libor - 3-month T-bill rate). The US TED spread is collected from FRED. Column (1) presents results estimating the effect of the buyer paying the fee using the whole time-series sample. Column (2) presents results of the asymmetric effect of the buyer paying the upfront fee on CDS spreads in the post-Small Bang sample (June 2009 - December 2019), while Columns (3) and (4) present these results between the Small Bang event and the end of the European Debt Crisis (EDC) (June 2009 - July 2012), and after the European Debt Crisis (August 2012 - December 2019), respectively. The dependent variable in all models is the first difference of CDS spreads ( $\triangle C D S$ spread). All estimations are carried out using firm fixed effects and standard errors clustered by firm. Data is collected from Bloomberg for the period January 2006 - December 2019.

\begin{tabular}{|c|c|c|c|c|}
\hline $\begin{array}{c}\text { Sample: } \\
\text { Period }\end{array}$ & $\begin{array}{l}\text { Whole Sample } \\
\text { Jan06-Dec19 } \\
\text { (1) }\end{array}$ & $\begin{array}{l}\text { Post-Small Bang } \\
\text { June09-Dec19 } \\
\text { (2) }\end{array}$ & $\begin{array}{c}\text { Small Bang - Debt Crisis } \\
\text { June09-July12 } \\
\text { (3) }\end{array}$ & $\begin{array}{c}\text { Post-Debt Crisis } \\
\text { Aug12-Dec19 } \\
\text { (4) }\end{array}$ \\
\hline Constant & $\begin{array}{c}-0.07 \\
{[-0.13]}\end{array}$ & $\begin{array}{c}-0.06 \\
{[-0.14]}\end{array}$ & $\begin{array}{c}1.33 \\
{[1.41]}\end{array}$ & $\begin{array}{c}-0.52 \\
{[-1.10]}\end{array}$ \\
\hline Return & $\begin{array}{c}-0.60 * * * \\
{[-6.39]}\end{array}$ & $\begin{array}{c}-0.59 * * * \\
{[-7.57]}\end{array}$ & $\begin{array}{c}-0.74 * * * \\
{[-5.26]}\end{array}$ & $\begin{array}{c}-0.50 * * * \\
{[-5.97]}\end{array}$ \\
\hline$\Delta$ Stock volatility & $\begin{array}{c}0.13^{*} \\
{[1.95]}\end{array}$ & $\begin{array}{c}0.06 \\
{[1.42]}\end{array}$ & $\begin{array}{c}-0.01 \\
{[-0.17]}\end{array}$ & $\begin{array}{l}0.10^{* *} \\
{[2.16]}\end{array}$ \\
\hline$\triangle C D S$ volatility & $\begin{array}{l}0.03 * * \\
{[2.23]}\end{array}$ & $\begin{array}{c}0.08 * * * \\
{[3.94]}\end{array}$ & $\begin{array}{c}0.11 * * * \\
{[3.16]}\end{array}$ & $\begin{array}{l}0.05^{* *} \\
{[2.38]}\end{array}$ \\
\hline$\Delta$ Stock bid-ask & $\begin{array}{c}-0.15 \\
{[-0.22]}\end{array}$ & $\begin{array}{c}0.13 \\
{[0.03]}\end{array}$ & $\begin{array}{c}-0.29 \\
{[-0.21]}\end{array}$ & $\begin{array}{c}0.16 \\
{[0.51]}\end{array}$ \\
\hline$\Delta C D S$ bid-ask & $\begin{array}{c}3.35 * * * \\
{[6.47]}\end{array}$ & $\begin{array}{c}1.98 * * * \\
{[5.21]}\end{array}$ & $\begin{array}{c}2.03 * * * \\
{[4.60]}\end{array}$ & $\begin{array}{c}2.07 * * * \\
{[3.46]}\end{array}$ \\
\hline$\Delta 10$-year risk-free rate & $\begin{array}{c}-11.18 * * \\
{[-2.11]}\end{array}$ & $\begin{array}{c}-5.32 \\
{[-1.25]}\end{array}$ & $\begin{array}{c}-0.75 \\
{[-0.13]}\end{array}$ & $\begin{array}{c}1.35 \\
{[0.15]}\end{array}$ \\
\hline$\Delta$ Slope yield & $\begin{array}{c}-0.94 \\
{[-0.11]}\end{array}$ & $\begin{array}{c}2.88 \\
{[0.54]}\end{array}$ & $\begin{array}{c}-0.88 \\
{[-0.14]}\end{array}$ & $\begin{array}{c}-0.02 \\
{[-0.00]}\end{array}$ \\
\hline$\triangle V S T O X X$ & $\begin{array}{l}0.40^{* *} \\
{[2.35]}\end{array}$ & $\begin{array}{c}0.49 * * * \\
{[3.69]}\end{array}$ & $\begin{array}{l}1.02 * * * \\
{[4.44]}\end{array}$ & $\begin{array}{c}0.19 \\
{[1.62]}\end{array}$ \\
\hline$\Delta F e e$ & $\begin{array}{c}-0.10 \\
{[-1.23]}\end{array}$ & $\begin{array}{c}-1.60 * * * \\
{[-9.37]}\end{array}$ & $\begin{array}{c}-1.63 * * * \\
{[-7.85]}\end{array}$ & $\begin{array}{c}-1.56^{* * *} \\
{[-6.65]}\end{array}$ \\
\hline$\Delta$ Fee $_{U S} \times$ Buyer & $\begin{array}{l}0.31 * * \\
{[2.21]}\end{array}$ & $\begin{array}{c}2.89 * * * \\
{[10.65]}\end{array}$ & $\begin{array}{c}2.76 * * * \\
{[8.47]}\end{array}$ & $\begin{array}{c}2.94 * * * \\
{[7.05]}\end{array}$ \\
\hline$\Delta$ Fee $_{U S} \times$ Buyer $\times S B$ & $\begin{array}{c}0.96 * * * \\
{[6.29]}\end{array}$ & & & \\
\hline $\begin{array}{c}\text { Observations: } \\
\text { R-squared: }\end{array}$ & $\begin{array}{c}17188 \\
0.45\end{array}$ & $\begin{array}{c}13189 \\
0.53\end{array}$ & $\begin{array}{r}3933 \\
0.59\end{array}$ & $\begin{array}{l}9256 \\
0.50\end{array}$ \\
\hline
\end{tabular}


Table A4 - Impact of Upfront Fee on CDS Spreads - Distinguishing Between Financial and Non-Financial Firms

Table A4 presents results highlighting the asymmetric effects of the exchange of upfront fees on CDS spreads written on financial and non-financial companies. The upfront fee is calculated as in Equation (2) but using the US TED spread (3month USD Libor - 3-month T-bill rate). The US TED spread is collected from FRED. Columns (1) and (2) explore the effects of the upfront fees on CDS spreads of financial entities for the whole time-series sample (January 2006 - December 2019) and post-Small Bang sample (June 2009 - December 2019), respectively. Columns (3) and (4) explore the effects of the upfront fees on CDS spreads of non-financial entities for the whole time-series sample and post-Small Bang sample, respectively. All estimations are carried out using firm fixed effects and standard errors clustered by firm. Data is collected from Bloomberg for the period January 2006 - December 2019.

\begin{tabular}{|c|c|c|c|c|}
\hline $\begin{array}{l}\text { Sample of firms } \\
\text { Sample Period }\end{array}$ & $\begin{array}{c}\text { Financial } \\
\text { Whole Sample } \\
\text { (1) }\end{array}$ & $\begin{array}{c}\text { Financial } \\
\text { Post-Small Bang } \\
\text { (2) }\end{array}$ & $\begin{array}{c}\text { Non-Financial } \\
\text { Whole Sample } \\
\text { (3) }\end{array}$ & $\begin{array}{c}\text { Non-Financial } \\
\text { Post-Small Bang } \\
\text { (4) }\end{array}$ \\
\hline Constant & $\begin{array}{c}-0.23 \\
{[-0.24]}\end{array}$ & $\begin{array}{c}-0.21 \\
{[-0.20]}\end{array}$ & $\begin{array}{c}-0.11 \\
{[-0.17]}\end{array}$ & $\begin{array}{c}-0.17 * * * \\
{[-0.31]}\end{array}$ \\
\hline Return & $\begin{array}{c}-0.80 * * * \\
{[-6.86]}\end{array}$ & $\begin{array}{c}-0.91 * * * \\
{[-6.06]}\end{array}$ & $\begin{array}{c}-0.70 * * * \\
{[-6.37]}\end{array}$ & $\begin{array}{c}-0.65 * * * \\
{[-7.87]}\end{array}$ \\
\hline$\Delta$ Stock volatility & $\begin{array}{c}0.01 \\
{[0.06]}\end{array}$ & $\begin{array}{c}0.01 \\
{[0.09]}\end{array}$ & $\begin{array}{l}0.22 * * * \\
{[2.63]}\end{array}$ & $\begin{array}{l}0.11^{* *} \\
{[2.22]}\end{array}$ \\
\hline$\triangle C D S$ volatility & $\begin{array}{c}0.04 \\
{[1.25]}\end{array}$ & $\begin{array}{l}0.10^{* *} \\
{[2.40]}\end{array}$ & $\begin{array}{l}0.04 * * * \\
{[2.34]}\end{array}$ & $\begin{array}{c}0.10^{* * *} \\
{[3.94]}\end{array}$ \\
\hline$\Delta$ Stock bid-ask & $\begin{array}{c}-0.91 \\
{[-0.79]}\end{array}$ & $\begin{array}{c}-0.79 \\
{[-0.87]}\end{array}$ & $\begin{array}{c}0.53 \\
{[0.68]}\end{array}$ & $\begin{array}{c}0.44 \\
{[0.63]}\end{array}$ \\
\hline$\triangle C D S$ bid-ask & $\begin{array}{l}2.88^{* * * *} \\
{[3.65]}\end{array}$ & $\begin{array}{l}2.33 * * * \\
{[3.00]}\end{array}$ & $\begin{array}{c}3.99 * * * \\
{[6.57]}\end{array}$ & $\begin{array}{c}2.26 * * * \\
{[4.91]}\end{array}$ \\
\hline$\Delta 10$-year risk-free rate & $\begin{array}{c}-6.64 \\
{[-0.79]}\end{array}$ & $\begin{array}{l}-11.76 \\
{[-1.17]}\end{array}$ & $\begin{array}{c}-13.04 * * \\
{[-2.13]}\end{array}$ & $\begin{array}{c}-5.04 \\
{[-0.99]}\end{array}$ \\
\hline$\Delta$ Slope yield & $\begin{array}{c}-8.33 \\
{[-0.55]}\end{array}$ & $\begin{array}{r}23.38 \\
{[1.34]}\end{array}$ & $\begin{array}{c}-0.41 \\
{[-0.04]}\end{array}$ & $\begin{array}{c}-2.26 \\
{[-0.34]}\end{array}$ \\
\hline$\triangle V S T O X X$ & $\begin{array}{l}1.00 * * * \\
{[3.37]}\end{array}$ & $\begin{array}{l}1.57 * * * \\
{[4.86]}\end{array}$ & $\begin{array}{l}0.39 * * \\
{[2.02]}\end{array}$ & $\begin{array}{l}0.54^{* * *} \\
{[3.60]}\end{array}$ \\
\hline$\Delta \mathrm{Fee}_{U S}$ & $\begin{array}{l}0.18 * * * \\
{[3.26]}\end{array}$ & $\begin{array}{r}0.15 \\
{[0.75]}\end{array}$ & $\begin{array}{l}0.10 * * \\
{[1.97]}\end{array}$ & $\begin{array}{l}0.73 * * * \\
{[5.44]}\end{array}$ \\
\hline $\begin{array}{l}\text { Observations: } \\
\text { R-squared: }\end{array}$ & $\begin{array}{l}3340 \\
0.43\end{array}$ & $\begin{array}{l}2540 \\
0.46\end{array}$ & $\begin{array}{c}13848 \\
0.39\end{array}$ & $\begin{array}{c}10566 \\
0.40\end{array}$ \\
\hline
\end{tabular}




\section{Table A5 - Impact of the Upfront Fee on CDS Spreads - Differences Across Industry Sectors}

Table A5 presents the impact of the upfront fees brought about by the CDS Small Bang on CDS spreads across five different industry sectors, using the specification presented in Eq. (6). The upfront fee is calculated as in Equation (2) but using the US TED spread (3-month USD Libor - 3-month T-bill rate). The US TED spread is collected from FRED. Column (1) presents results of the effect of the upfront fee on CDS spreads using the whole sample (January 2006 - December 2009). Column (2) presents results of the effect of the upfront fee on CDS spreads in the post-Small Bang sample (June 2009 - December 2019). Column (3) presents results of the effect of the upfront fee between the Small Bang event and the end of the European Debt Crisis (June 2009 - July 2012). Column (4) presents results of the effect of the upfront fee after the European Debt Crisis (August 2012 - December 2019). The dependent variable in all models is the first difference of CDS spreads ( $\triangle C D S$ spread). All estimations are carried out using firm fixed effects and standard errors clustered by firm. Data is collected from Bloomberg for the period January 2006 - December 2019.

\begin{tabular}{|c|c|c|c|c|}
\hline $\begin{array}{c}\text { Sample: } \\
\text { Period }\end{array}$ & $\begin{array}{l}\text { Whole Sample } \\
\text { Jan06-Dec19 } \\
\text { (1) }\end{array}$ & $\begin{array}{l}\text { Post-Small Bang } \\
\text { June09-Dec19 } \\
\text { (2) }\end{array}$ & $\begin{array}{c}\text { Small Bang - Debt Crisis } \\
\text { June09-July12 } \\
\text { (3) }\end{array}$ & $\begin{array}{c}\text { Post-Debt Crisis } \\
\text { Aug12-Dec19 } \\
\text { (4) }\end{array}$ \\
\hline Constant & $\begin{array}{c}-0.12 \\
{[-0.19]}\end{array}$ & $\begin{array}{c}-0.16 \\
{[-0.27]}\end{array}$ & $\begin{array}{c}1.77 \\
{[1.41]}\end{array}$ & $\begin{array}{c}-0.75 \\
{[-1.28]}\end{array}$ \\
\hline Return & $\begin{array}{c}-0.73 * * * \\
{[-7.84]}\end{array}$ & $\begin{array}{c}-0.73^{* * *} \\
{[-8.49]}\end{array}$ & $\begin{array}{c}-0.95 * * * \\
{[-5.89]}\end{array}$ & $\begin{array}{c}-0.61 * * * \\
{[-7.34]}\end{array}$ \\
\hline$\Delta$ Stock volatility & $\begin{array}{c}0.17 * * * \\
{[2.71]}\end{array}$ & $\begin{array}{c}0.09^{*} \\
{[1.88]}\end{array}$ & $\begin{array}{c}0.03 \\
{[0.35]}\end{array}$ & $\begin{array}{c}0.14 * * * \\
{[2.65]}\end{array}$ \\
\hline$\triangle C D S$ volatility & $\begin{array}{l}0.04^{* *} \\
{[2.31]}\end{array}$ & $\begin{array}{c}0.10^{* * * *} \\
{[4.35]}\end{array}$ & $\begin{array}{c}0.12 * * * \\
{[2.84]}\end{array}$ & $\begin{array}{c}0.08^{* * *} \\
{[3.18]}\end{array}$ \\
\hline$\Delta$ Stock bid-ask & $\begin{array}{c}0.03 \\
{[0.05]}\end{array}$ & $\begin{array}{c}0.12 \\
{[0.20]}\end{array}$ & $\begin{array}{c}0.11 \\
{[0.07]}\end{array}$ & $\begin{array}{c}0.18 \\
{[0.47]}\end{array}$ \\
\hline$\Delta C D S$ bid-ask & $\begin{array}{c}3.73 * * * \\
{[6.58]}\end{array}$ & $\begin{array}{c}2.27 * * * \\
{[5.23]}\end{array}$ & $\begin{array}{c}2.31 * * * \\
{[4.73]}\end{array}$ & $\begin{array}{c}2.35^{* * *} \\
{[3.46]}\end{array}$ \\
\hline$\Delta 10$-year risk-free rate & $\begin{array}{c}-11.96^{* *} \\
{[-2.00]}\end{array}$ & $\begin{array}{c}-6.55 \\
{[-1.20]}\end{array}$ & $\begin{array}{c}1.86 \\
{[0.26]}\end{array}$ & $\begin{array}{c}-0.43 \\
{[-0.04]}\end{array}$ \\
\hline$\Delta$ Slope yield & $\begin{array}{c}-2.26 \\
{[-0.27]}\end{array}$ & $\begin{array}{c}2.99 \\
{[0.40]}\end{array}$ & $\begin{array}{c}-2.10 \\
{[-0.24]}\end{array}$ & $\begin{array}{c}0.72 \\
{[0.05]}\end{array}$ \\
\hline$\triangle V S T O X X$ & $\begin{array}{l}0.50^{* *} \\
{[2.53]}\end{array}$ & $\begin{array}{c}0.72 * * * \\
{[4.32]}\end{array}$ & $\begin{array}{l}1.41 * * * \\
{[4.98]}\end{array}$ & $\begin{array}{l}0.35^{* *} \\
{[2.43]}\end{array}$ \\
\hline$\Delta \mathrm{Fee}_{U S} \times I_{\text {Automobile \& Industrials }}$ & $\begin{array}{l}0.13^{*} \\
{[1.90]}\end{array}$ & $\begin{array}{c}0.77 * * * \\
{[4.89]}\end{array}$ & $\begin{array}{c}0.59 * * * \\
{[4.10]}\end{array}$ & $\begin{array}{l}0.81 * * \\
{[2.36]}\end{array}$ \\
\hline$\Delta \mathrm{Fee}_{U S} \times I_{\text {Consumer Products }}$ & $\begin{array}{c}0.04 \\
{[0.65]}\end{array}$ & $\begin{array}{c}0.88^{* * * *} \\
{[6.57]}\end{array}$ & $\begin{array}{c}0.86 * * * \\
{[6.57]}\end{array}$ & $\begin{array}{l}0.80^{* * *} \\
{[3.75]}\end{array}$ \\
\hline$\Delta \mathrm{Fee}_{U S} \times I_{\text {Energy }}$ & $\begin{array}{c}0.04 \\
{[0.40]}\end{array}$ & $\begin{array}{c}0.47 \\
{[1.52]}\end{array}$ & $\begin{array}{c}0.54 \\
{[1.34]}\end{array}$ & $\begin{array}{c}0.13 \\
{[0.36]}\end{array}$ \\
\hline$\Delta$ Fee $_{U S} \times I_{\text {Financials }}$ & $\begin{array}{c}0.15^{* * *} \\
{[3.39]}\end{array}$ & $\begin{array}{c}0.29 \\
{[1.48]}\end{array}$ & $\begin{array}{c}0.01 \\
{[0.05]}\end{array}$ & $\begin{array}{c}0.81^{* * *} \\
{[4.41]}\end{array}$ \\
\hline$\Delta$ Fee $_{U S} \times I_{\text {Telecoms, }}$ Media \& Tech & $\begin{array}{c}0.18^{* * *} \\
{[2.77]}\end{array}$ & $\begin{array}{c}0.30 \\
{[1.59]}\end{array}$ & $\begin{array}{c}0.15 \\
{[0.57]}\end{array}$ & $\begin{array}{c}0.35 \\
{[1.64]}\end{array}$ \\
\hline $\begin{array}{l}\text { Observations: } \\
\text { R-squared: }\end{array}$ & $\begin{array}{c}17188 \\
0.39\end{array}$ & $\begin{array}{c}13189 \\
0.41\end{array}$ & $\begin{array}{l}3933 \\
0.47\end{array}$ & $\begin{array}{c}9256 \\
0.38\end{array}$ \\
\hline
\end{tabular}

